\title{
Evaluation of Molecular Markers for Phytophthora ramorum Detection and Identification: Testing for Specificity Using a Standardized Library of Isolates
}

\author{
F. N. Martin, M. D. Coffey, K. Zeller, R. C. Hamelin, P. Tooley, M. Garbelotto, K. J. D. Hughes, \\ T. Kubisiak, G. J. Bilodeau, L. Levy, C. Blomquist, and P. H. Berger
}

First author: United States Department of Agriculture-Agricultural Research Service (USDA-ARS), Salinas, CA; second author: University of California, Riverside; third and tenth authors: USDA Animal and Plant Health Inspection Service (APHIS), PPQ, CPHST, NPGBL, Beltsville, MD; fourth and ninth authors: Natural Resources Canada, Canadian Forest Service, Quebec, QC, Canada; fifth author: USDAARS, Ft. Detrick, MD; sixth author: University of California, Berkeley; seventh author: Central Science Lab, York, UK; eighth author: USDA Forest Service, Southern Research Station, Southern Institute of Forest Genetics, Saucier, MS; eleventh author: California Department of Food and Agriculture, Plant Pest Diagnostics Branch, Sacramento; and twelfth author: USDA-APHIS-PPQ-CPHST, Raleigh, NC.

Accepted for publication 29 December 2008.

\section{ABSTRACT}

Martin, F. N., Coffey, M. D., Zeller, K., Hamelin, R. C., Tooley, P., Garbelotto, M., Hughes, K. J. D., Kubisiak, T., Bilodeau, G. J., Levy, L., Blomquist, C., and Berger, P. H. 2009. Evaluation of molecular markers for Phytophthora ramorum detection and identification: Testing for specificity using a standardized library of isolates. Phytopathology 99:390-403.

Given the importance of Phytophthora ramorum from a regulatory standpoint, it is imperative that molecular markers for pathogen detection are fully tested to evaluate their specificity in detection of the pathogen. In an effort to evaluate 11 reported diagnostic techniques, we assembled a standardized DNA library using accessions from the World Phytophthora Genetic Resource Collection for 315 isolates representing 60 described Phytophthora spp. as well as 11 taxonomically unclassified isolates. These were sent blind to collaborators in seven laboratories to evaluate published diagnostic procedures using conventional (based on internal transcribed spacer [ITS] and cytochrome oxidase gene [cox] 1 and 2 spacer regions) and real-time polymerase chain reaction (based on ITS and coxl and 2 spacer regions as well as $\beta$-tubulin and elicitin genes). Single-strand conformation polymorphism (SSCP) analysis using an automated sequencer for data collection was also evaluated for identification of all species tested. In general, the procedures worked well, with varying levels of specificity observed among the different techniques. With few exceptions, all assays correctly identified all isolates of $P$. ramorum and low levels of false positives were observed for the mitochondrial cox spacer markers and most of the real-time assays based on nuclear markers (diagnostic specificity between 96.9 and 100\%). The highest level of false positives was obtained with the conventional nested ITS procedure; however, this technique is not stand-alone and is used in conjunction with two other assays for diagnostic purposes. The results indicated that using multiple assays improved the accuracy of the results compared with looking at a single assay alone, in particular when the markers represented different genetic loci. The SSCP procedure accurately identified $P$. ramorum and was helpful in classification of a number of isolates to a species level. With one exception, all procedures accurately identified $P$. ramorum in blind evaluations of 60 field samples that included examples of plant infection by 11 other Phytophthora spp. The SSCP analysis identified eight of these species, with three identified to a species group.
In the short time since its initial description in 2002, Phytophthora ramorum has become an important pathogen in North America and Europe. Because of its broad host range, distribution in nursery production systems, and devastating impact on forest ecosystems, there are quarantine restrictions in place to deter its spread into uninfested areas $(5,6,26)$. Although it was initially suggested that California populations may have been introduced from European nurseries, subsequent work confirmed that the populations in the two continents were clonal and distinct from each other $(15,16)$. Differences in growth rate and mating type were also observed, with the A2 mating type representing isolates

Corresponding author: F. Martin; E-mail address: frank.martin@ars.usda.gov

The $e$-Xtra logo stands for "electronic extra" and indicates that the online version includes additional details on the procedures used, the data files generated with the SSCP procedure, and the data matrices used in their analysis.

doi:10.1094/PHYTO-99-4-0390

This article is in the public domain and not copyrightable. It may be freely reprinted with customary crediting of the source. The American Phytopathological Society, 2009. from natural ecosystems and nurseries in North America while those in Europe were the A1 mating type. However, there has been a report of $\mathrm{A} 2$ mating types in Belgium and $\mathrm{A} 1$ mating types in North American nurseries $(3,11,15,35)$. Based on microsatellite analysis, a third nuclear lineage of the pathogen also has been reported in North American nurseries (15)

A range of methods is currently in use by the regulatory and research communities to detect the pathogen from infected plant material. Although it is possible to culture the organism and positively identify it based on morphological characteristics, problems have been encountered with recovery from specific hosts when samples have not been properly handled when in transit to the lab or when collections are made at certain times of the year (12, 13,27). Enzyme-linked immunosorbent assay (ELISA) also has been used as a prescreen for the pathogen in the United States Department of Agriculture (USDA) Animal and Plant Health Inspection Service (APHIS)-approved screening program (32) but the available polyclonal antiserum can cross-react with some Pythium spp. and cannot detect $P$. ramorum specifically. Several molecular techniques are capable of detection of Phytophthora spp. at a genus level directly from infected plant material using 
markers developed from the internal transcribed spacer (ITS) region (9) and the cytochrome oxidase gene [cox] 1 and 2 spacer region (25). Additional techniques for identification of Phytophthora spp. in general also identify $P$. ramorum; however, the described techniques require pure cultures of the pathogen for DNA extraction. For example, Kong et al. $(18,19)$ described an approach using a portion of the ITS region of the ribosomal DNA (ITS-rDNA) in single-strand conformation polymorphism (SSCP) analysis while Martin and Tooley (24) reported a polymerase chain reaction (PCR) restriction fragment length polymorphism (RFLP) technique using the mitochondrially encoded coxl and $\operatorname{cox} 2$ gene cluster.

From a diagnostics and regulatory perspective, a more suitable approach would be to employ diagnostic methods that are highly specific and sensitive for the target pathogen that can be used directly on infected plant tissue without the need for culturing. One of the early techniques described and adopted as the standard molecular detection method by the USDA-APHIS-PPQ was a nested amplification in the ITS region of the rDNA by conventional PCR $(10,34)$. Another molecular detection system using the same target region designed to detect $P$. lateralis in a single round of amplification (37) was also found to amplify P. ramorum (34). This procedure had the added benefit that it is a multiplex amplification with an additional set of primers serving as a positive control to confirm the suitability of the extracted DNA for PCR amplification, thereby safeguarding against the generation of false negative results. Two additional techniques have been described that use the cox genes as target sequences. Kroon et al. (21) described a technique where RFLP analysis of the amplicon from a portion of the coxl gene differentiates $P$. ramorum from other species, as well as differentiates European isolates from North American isolates. However, this technique will not differentiate the third nuclear lineage of $P$. ramorum that was detected in some North American nurseries. A nested PCR approach using the spacer region between the coxl and $\operatorname{cox} 2$ genes and flanking coding regions was developed (25), with the first-round amplification generating a genus-specific amplicon that is diagnostic for the presence of a Phytophthora spp. and a second-round species-specific amplification for detection of $P$. ramorum. This technique also includes a plant DNA amplification control in the first round, which serves as an internal control for the quality of the extracted DNA. RFLP analysis of the genus-specific amplicon was recently reported to differentiate the third lineage from North American nurseries (22).

Several real-time PCR techniques for species-specific detection also have been developed. Hayden et al. (13) reported a nestedPCR detection technique using the same primers as the conventional ITS nested detection method (10), with the exception that the nested amplification was done using SYBR green. The amplification was also multiplexed with a primer pair that amplified a region of the $28 \mathrm{~S}$ rDNA from plants to serve as an internal positive control. This technique was recently modified for TaqMan chemistry using the same first-round primer pair but different nested primers for detection of P. ramorum (12). Likewise, Hughes et al. (14) reported a TaqMan real-time PCR technique based on the ITS region. While using these same primers, Tomlinson et al. (29) compared the TaqMan, Scorpion, and Molecular Beacon detection methods as well as loop-mediated isothermal amplification technique for detection of the pathogen. Tomlinson et al. (30) also describes a modification of the Hughes et al. (14) TaqMan assay suitable for on-site use. More recently, Bilodeau et al. (2) reported on a TaqMan marker system based on the ITS region of the rDNA, the elicitin gene, and the $\beta$-tubulin gene, thereby using three different genetic loci to make a diagnosis. These authors also compared the sensitivity of SYBR green, TaqMan, and Molecular Beacon real-time PCR methods for the $\beta$ tubulin gene marker. Schena et al. (28) reported a multiplex detection method for $P$. ramorum, $P$. kernoviae, $P$. quercina, and $P$. citricola based on regions of the ras-related protein (Yptl) gene. The species-specific detection system for $P$. ramorum based on the cox 1 and $\operatorname{cox} 2$ spacer region and the plant positive control also has been adapted for multiplex amplification using TaqMan realtime PCR (31).

Current USDA-APHIS-PPQ procedures for molecular detection of $P$. ramorum utilize a combination of three of the abovementioned procedures (34). The two conventional PCR techniques used are the nested PCR procedure of Garbelotto et al. (10) for detection of $P$. ramorum and the multiplex amplification for $P$. lateralis described by Winton and Hanson (37), which has an additional primer pair for a positive control to confirm the quality of the extracted DNA. More recently, a modification of the Central Science Laboratory (CSL) real-time PCR technique using the ITS region described by Hughes et al. (14) was validated for $P$. ramorum detection and added to the USDA-APHIS-PPQ confirmation testing protocol (33). The results of all three of these assays are evaluated before a diagnosis is determined. When an unambiguous diagnosis cannot be made with these combined assays or when samples from new hosts of new areas are being examined, the PCR results are confirmed by DNA sequence analysis.

Given the importance of having a highly specific molecular diagnostic technique, as well as several techniques relying on different genetic regions for running confirmatory diagnostics, the objective of this research was to evaluate a number of the described molecular techniques $(2,12,14,25,31,37)$ against a defined panel of Phytophthora spp. to evaluate specificity in side-by-side comparisons and identify the strengths and weakness of each assay. In addition, a modification of the SSCP technique described by Kong et al. (18,19), using ABI 3100 and 3130XL fluorescence-based capillary platforms for data collection, was evaluated for its utility as a specific diagnostic for $P$. ramorum as well as a general diagnostic for Phytophthora spp. Although these marker systems were tested at various levels for specificity in the manuscripts that reported them, the same isolates of Phytophthora were not used among the tests and an evaluation including most of the described species in the genus was not conducted. For this reason, the evaluation reported in this study used a standard library of DNA purified from cultures of Phytophthora spp. representing a broad geographic range for most of the described species. This library was sent blind to all cooperating labs. A second set of DNAs extracted from field samples in which a Phytophthora sp. had been positively identified also were sent blind and assayed by the different techniques.

\section{MATERIALS AND METHODS}

Cultures and DNA extraction. Isolates used in this experimentation were from the World Phytophthora Genetic Resource Collection (WPC) at the University of California, Riverside (available online at the University of California) and are listed in Table 1. In total, 315 isolates representing 60 described species and 11 isolates with ambiguous taxonomic classification were included, as were several Pythium spp. to serve as an outgroup. Isolates with an ambiguous taxonomic classification were included because they represent putative new species for which the taxonomic descriptions are currently in progress; the species names will be updated at the WPC website as they become available. In all, 47 isolates of $P$. ramorum were included in the evaluations.

All culture work and DNA extraction was done in the lab of M. Coffey at the University of California, Riverside. The majority of cultures were grown on liquid clarified V8 (1:2 dilution) broth (1) at $24^{\circ} \mathrm{C}$ for 4 to 8 days prior to harvest and the washed mycelium was flash frozen in liquid nitrogen prior to storage at $-80^{\circ} \mathrm{C}$. Cultures of $P$. infestans were grown on Rye seed broth (7) at $18^{\circ} \mathrm{C}$ for 10 to 14 days. DNA was extracted from 100 to $250 \mathrm{mg}$ of 
tissue using a FastDNA extraction kit and FastPrep FP 120 instrument (Qbiogene, Carlsbad, CA) in conjunction with a FastPrep Cell Disrupter using the manufacturers' recommendations for plant tissues with the following modifications: $1,000 \mu \mathrm{l}$ of CLS-VF were substituted for $800 \mu$ of CLS-VF and $200 \mu \mathrm{l}$ of PPS. DNA concentrations were determined spectrophotometrically using either a Beckman DU-64 UV or Nanodrop spectrophotometer (ND-1000; Nanodrop Technologies, Wilmington, DE) and adjusted to $10 \mathrm{ng} / \mu \mathrm{l}$ in low Tris-EDTA (TE) buffer $(10 \mathrm{mM}$ Tris, $0.1 \mathrm{mM}$ EDTA, $\mathrm{pH}$ 8.0). Aliquots were coded and sent blind to all participants (457 samples were sent in six batches). The ITS region and the $\operatorname{cox} 2$ gene for all extracts were also amplified and sequenced using previously reported procedures $(8,23)$ to confirm the identity of the DNA samples. Some samples were sent multiple times; when this was done, they were recoded so that the species identities remained blind to the participants.

Field samples. Samples of DNA extracted from symptomatic plants collected from the field were processed at the California Department of Food and Agriculture (CDFA) using USDAAPHIS-PPQ-approved procedures (32). Leaf pieces with lesions were cut in half, with one half plated on PARP medium (17) for selective isolation of Phytophthora spp. and the other half tested by ELISA for the presence of Phytophthora spp. The species identification of the cultures that grew out was by sequence analysis of the ITS region using primers ITS1 and ITS4 (36). For samples in which ELISA was positive but cultures did not grow out, the leaf tissue was resampled for DNA extraction and approved USDA-APHIS-PPQ procedures were used for molecular detection of $P$. ramorum (34). To reconfirm the identity of Phytophthora spp. present in the samples sent to the cooperators in this trial, the ITS amplicons used in the SSCP analysis and the Phytophthora genus-specific amplicon of Martin et al. (25) spanning the spacer region between the $\operatorname{cox} 1$ and 2 genes were sequenced in both directions using the same primers for sequencing that were used for amplification $(18,25)$.

Diagnostics tests evaluated. In total, 11 different diagnostic assays for detection of $P$. ramorum were evaluated, in most cases in the same labs that developed the technique (Table 2). Unless otherwise indicated, all procedures followed the protocols previously published. The SSCP technique initially described by Kong et al. (18) was modified for running on an automated DNA sequencer at the USDA Forest Service, Southern Institute of Forest Genetics. Each sample $(1 \mu \mathrm{l})$ was PCR amplified in replicate using the oomycete-specific primers ITS6 and ITS7 as described in Kong et al. (18). ITS6 was fluorescently 5'-end labeled with 6-FAM and ITS7 with HEX. A 1:10 dilution of the PCR product was denatured and analyzed using the default criteria specified in the "High Throughput Fluorescent SSCP Analysis User Bulletin" from Applied Biosystems (Foster City, CA) on an ABI3100 (bulletin can be found at Applied Biosystems website).

TABLE 1. List of Phytophthora spp. included in this investigation and their isolate numbers and origin of recovery

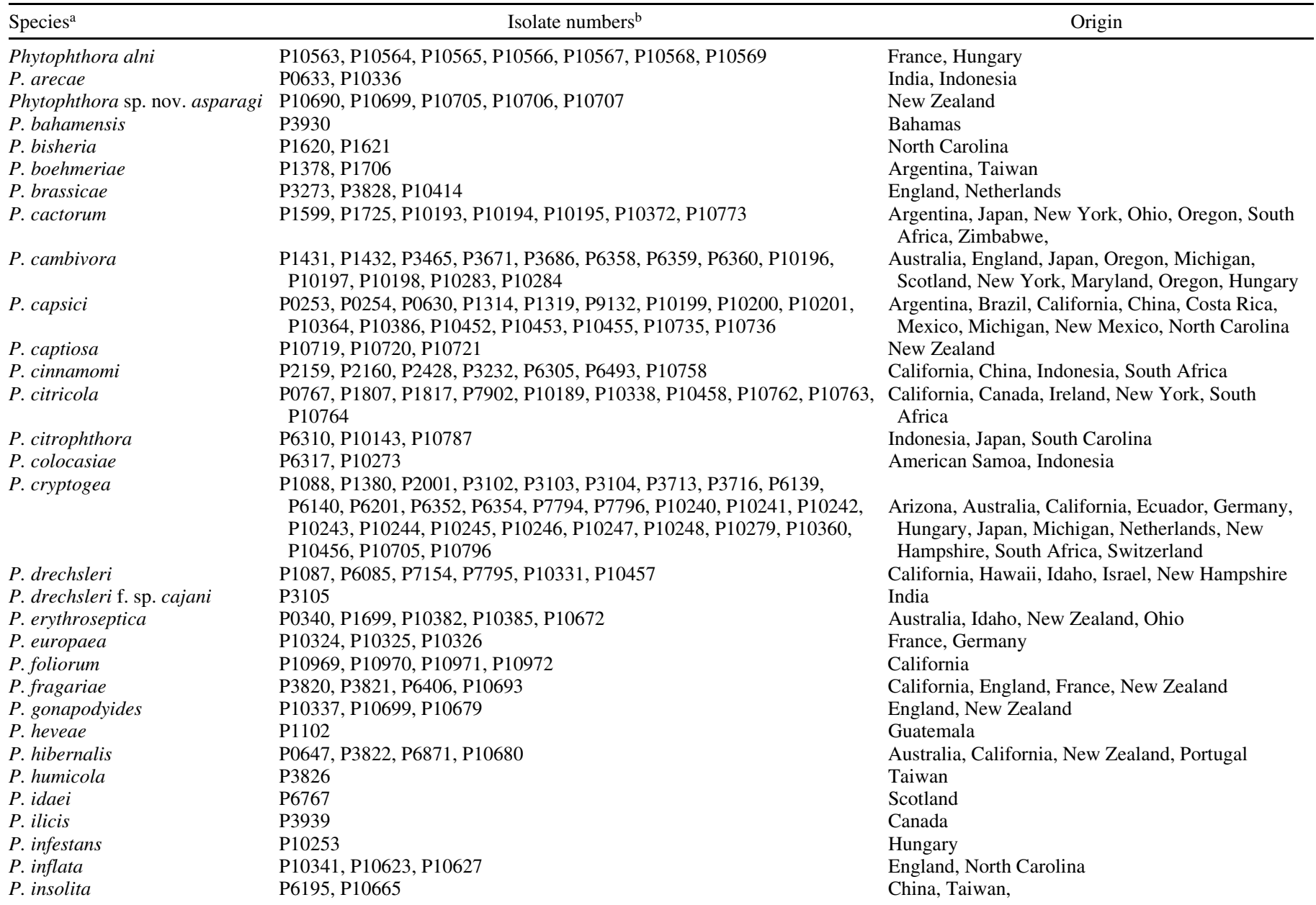

(continued on next page)

a Species identification was confirmed by sequence analysis of the internal transcribed spacer region and the cox 2 gene (data can be found at Phytophthora database online).

${ }^{b}$ Additional information on isolates may be obtained at the website for the World Phytophthora Genetic Resource Collection at the University of California, Riverside (available online).

${ }^{\mathrm{c}}$ Represent species that have not yet been formally described. 
Amplified products from all of the samples were separated on an ABI 3100 genetic analyzer using 5\% GeneScan polymer containing $10 \%$ glycerol. Amplified products from a subset of samples were also separated on an ABI 3130 XL using 9\% CAP polymer containing $10 \%$ glycerol. All runs were performed using an oven temperature of $20^{\circ} \mathrm{C}$. For both machines and polymer types, ROX500 was used as an internal migration rate standard. To set up a robust migration rate standard for automated scoring, ROX500 peaks that had consistently strong signal strength were identified by examining peak heights across a number of capillaries. Eight consistently strong ROX500 signal peaks were identified using the ABI 3100 and 5\% GeneScan polymer, whereas nine were identified using the ABI $3130 \mathrm{XL}$ and 9\% CAP polymer. Adjusted scanline values (observed scanline values divided by 10) were assigned to these peaks using the data from a single capillary. Standardized ROX500 values were then used to estimate adjusted scanline values for all 6-FAM and HEX peaks. Adjusted 6-FAM and HEX scanline values were then converted back to approximate scanline values by multiplying by 10 . Using these separation protocols, only two main peaks (one 6-FAM and one HEX) were observed for a number of isolates and species in contrast to the typical four-banded pattern previously reported using slab gel systems (18). For those isolates and species where multiple peaks were observed, only the 6-FAM and HEX peaks with the largest peak height/area under the peak were used for data analyses (i.e., mean tests and unweighted pair group method with arithmetic means). Mean and standard deviation of scanline estimates for each species were dependent upon the number of isolates analyzed per species, with a minimum of two reads per sample.

Whereas the DNA concentration from purified cultures used in most diagnostic assays was $1 \mu \mathrm{l}$ of the supplied concentration of $10 \mathrm{ng} / \mu \mathrm{l}$, in several cases it was diluted. For the UCB-nested ITS TaqMan real-time procedure of Hayden et al. (12) done in the Garbelotto lab, the DNA was diluted 1:100,000 before adding $6.25 \mu \mathrm{l}$ to the first-round amplification $(62.5 \mathrm{fg}$ in a $25-\mu \mathrm{l}$ final volume); for the second amplification, the first round was diluted $1 / 500$ and $5 \mu \mathrm{l}$ was added to the master mix (final volume of $15 \mu \mathrm{l})$. For the three tests performed by the USDA-APHIS-PPQNPGBL (Table 2), the DNA was diluted 1:10 and $6 \mu \mathrm{l}$ of this was added to the amplification reaction (6 ng DNA in a $25-\mu$ l final volume). DNA samples from environmental samples from the field were used at a rate of $1 \mu \mathrm{l}$ of a 1:10 dilution of the initial DNeasy-extracted DNA in all assays (this is consistent with the approved USDA-APHIS procedure).

Notes on sample scoring. The suitability of the DNA for PCR amplification was demonstrated for all culture-extracted DNA by amplification of two regions used for sequence analysis to confirm isolate identification. The ability to amplify DNA from all field samples was confirmed by amplification of the ITS region in

TABLE 1. (continued from preceding page)

\begin{tabular}{|c|c|c|}
\hline Species $^{\mathrm{a}}$ & Isolate numbers ${ }^{\mathrm{b}}$ & Origin \\
\hline P. inundata & P8478, P10669 & California, England \\
\hline P. katsurae & P3389 & New Guinea \\
\hline P. kernoviae & P10681, P10956, P10957 & England, New Zealand \\
\hline P. macrochlamydospora & P8017, P10263, P10264, P10266, P10267, P10269 & Australia \\
\hline P. meadii & P6128, P6262, P6508, P10190, P10191 & India \\
\hline P. medicaginis & P3176, P7029, P10683, P10686 & California, New Zealand, Wisconsin \\
\hline P. megasperma & P3136, P3162, P3600, P3715, P6046, P6471, P10340 & $\begin{array}{l}\text { New Zealand, Australia, Japan, England, Michigan, } \\
\text { Oregon }\end{array}$ \\
\hline P. mexicana & P0646 & Mexico \\
\hline P. mirabilis & P3005, P3006, P3007, P3008, P3009, P3010 & Mexico \\
\hline P. multivesiculata & P10327, P10410, P10525, P10670, P10700 & Netherlands, New Zealand \\
\hline P. nemorosa & P10612 & California \\
\hline P. nicotianae & $\begin{array}{l}\text { P1325, P1452, P6303, P7146, P10116, P10280, P10362, P10451, P10718, } \\
\text { P10802, P10803 }\end{array}$ & California, Indonesia, Japan, Hungary, Mexico \\
\hline P. palmivora & P0113, P0255, P0674, P0739, P10272, P10769 & $\begin{array}{l}\text { American Samoa, Costa Rica, Ghana, Guam, } \\
\text { Hawaii, Uganda, }\end{array}$ \\
\hline P. pseudosyringae & P10437, P10442, P10443, P10444 & France, Germany \\
\hline P. pseudotsugae & P10218, P10339 & Oregon, \\
\hline P. psychrophila & P10433, P10434, P10435 & France, Germany \\
\hline P. quercina & P10334, P10438, P10439, P10440, P10441 & Germany, Serbia, \\
\hline P. ramorum & $\begin{array}{l}\text { P10090, P10091, P10102, P10103, P10132, P10135, P10301, P10303, } \\
\text { P10306, P10307, P10309, P10310, P10312, P10313, P10314, P10316, } \\
\text { P10317, P10318, P10319, P10320, P10321, P10322, P10323, P10343, } \\
\text { P10465, P10467, P10473, P10474, P10477, P10475, P10487, P10502, } \\
\text { P10504, P10505, P10509, P10511, P10546, P10637, P10960, P11014, } \\
\text { P11047, P11048, P11049, P11050, P11051, P11122, P11333 }\end{array}$ & $\begin{array}{l}\text { Belgium, California, England, Germany, } \\
\text { Netherlands, Oregon, Poland, South Carolina, } \\
\text { Washington }\end{array}$ \\
\hline P. richardiae & P3876, P6875, P7788, P7789, P10335, P10355, P10358, P10359, P10811 & $\begin{array}{l}\text { England, Japan, United States, New Hampshire, } \\
\text { Netherlands }\end{array}$ \\
\hline P. sojae & P3114, P10709 & New Zealand, Wisconsin \\
\hline Phytophthora spp. ${ }^{\mathrm{c}}$ & $\begin{array}{l}\text { P1679, P6306, P7907, P8103, P8213, P8485, P10281, P10282, P10369, } \\
\text { P10704, P10708 }\end{array}$ & $\begin{array}{l}\text { Argentina, California, Ecuador, Hungary, Indonesia, } \\
\text { Malaysia, New Zealand, Oregon }\end{array}$ \\
\hline
\end{tabular}


the SSCP analysis and the cox spacer region genus-specific amplicon, both of which were used for sequence analysis to confirm the identity of the Phytophthora sp. present. In addition, the following diagnostic assays also had internal positive controls that were included in all amplifications to ensure the suitability of the DNA for amplification: the USDA-APHIS-approved multiplex amplification for $P$. lateralis (37), the UCB-nested ITS TaqMan real-time procedure (12), and the CSL ITS TaqMan real-time assay of Hughes et al. (14).

Real-time PCR positives for $P$. ramorum were based on a positive result with a cycle threshold $\left(\mathrm{C}_{\mathrm{t}}\right)$ cut-off of 40 for the cox spacer region (31), the UCB-nested ITS TaqMan real-time assay of Hayden et al. (12), and the NRC ITS and $\beta$-tubulin TaqMan real-time PCR assays of Bilodeau et al. (2) (the elicitin assay had a $C_{t}$ cutoff of 34). For the CSL ITS TaqMan real-time procedure (14), PCR positives were scored on a $C_{t}$ cut-off of 36 ; below 36 , they were scored as positive; between 36 and 40 they were scored as a retest (if the tests had been done with plant samples they would have been re-extracted if material was available); and samples giving $C_{t}$ of 40 were scored as PCR negative. For the USDA-APHIS-PPQ-approved molecular diagnostic procedures conducted at the USDA-APHIS-PPQ-NPGBL, conclusions on positive samples were based on the results of the three assays that were performed. A retest of the samples would have been triggered by the sample DNA producing a conventional nested PCR band from at least one of the two tested DNA dilutions (1:10 and 1:100 in double-distilled $\mathrm{H}_{2} \mathrm{O}$ of the provided DNA stock), not producing a Phytophthora multiplex PCR band with the $P$. lateralis primers of Winton and Hansen (37), and reacting weakly $\left(C_{t}\right.$ values $\left.>30\right)$ or not at all with the USDA-APHIS-PPQapproved modified CSL ITS TaqMan real-time assay. Similar to the CSL scoring noted above, samples with a $\mathrm{C}_{\mathrm{t}}$ between 36 and 40 would be scored as a retest or the results confirmed with the nested ITS procedure. When the results observed for assays on DNA extracted from symptomatic plant material were ambiguous, the amplicons would be sequenced to confirm correct diagnosis.

Analysis of sensitivity and specificity of the diagnostic procedures. To quantify the accuracy of pathogen detection for the techniques evaluated, the procedures used by Kox et al. (20) were used to calculate diagnostic sensitivity (proportion of true positives correctly identified), diagnostic specificity (proportion of true negatives correctly identified), positive predictive value (PPV) (proportion of samples with positive results correctly identified), and negative predictive value (NPV) (proportion of samples with negative results correctly identified). The calculations for diagnostic specificity and NPV were modified to include samples rated as retest in the denominator because the assay did not conclusively identify these samples as negative.

\section{RESULTS}

With the exception of the results presented below, all samples in all diagnostic procedures were positive for detection of $P$. ramorum and negative for all other species tested. A summary of the test results is presented in Table 3 .

False negatives. In total, 67 samples of $P$. ramorum were sent out representing 47 isolates from nine locations (Table 1) and, with few exceptions, all were correctly identified (Table 3 ). One of these exceptions was isolate P10303 (=CBS 101330); the CSL ITS TaqMan real-time procedure of Hughes et al. (14) had a false negative one of two times it was run and the UCB-nested ITS TaqMan real-time procedure of Hayden et al. (12) gave a false negative both times the sample was run. Isolate P10318 also gave a false negative with the UCB-nested ITS TaqMan real-time procedure of Hayden et al. (12) one of three times the sample was run, as did the conventional nested PCR cox spacer marker (Table 3 ). One possible reason for the false negative one of three times the sample was run for isolate P10318 with the UCB-nested ITS TaqMan real-time procedure of Hayden et al. (12) is that there is an SNP at position 616 in ITS sequence with a $\mathrm{C}$ replacing a $\mathrm{T}$. This position is the second base from the $3^{\prime}$ end for primer Pram5 (the forward primer of the nested TaqMan marker of Hayden et al.) (12) and an SNP at this position may affect the ability of the primer to anneal. From reviewing 71 depositions in GenBank, there are four other isolates of $P$. ramorum recovered from ornamental plants in Spain (EF050515 and EF050516), France (AY845186), and Switzerland (AY833607) that have this same SNP. However, this region appears to be difficult to get a clean sequence from because some of the other accessions were ambiguous for this position.

False positives. Mitochondrial marker: cox spacer region. False positives were obtained with the conventional cox spacer nested PCR technique (25) for two samples: P. porri (one of two isolates) and $P$. uliginosa (one isolate one of three times the sample was run) (Tables 3 and 4). When running the cox spacer region real-time PCR marker system of Tooley et al. (31), false positives were observed with $P$. arecae (one of two isolates tested), $P$. porri (one of two isolates), $P$. quercina (one of five isolates), $P$. richardiae (one of nine isolates with an atypical amplification curve), $P$. uliginosa (one isolate two of four times the sample was run), and a Pythium sp. ( $\mathrm{C}_{\mathrm{t}}$ was 39.7$)$. False positives were observed for several other species but the results were not consistent among isolates of the species or the different times the

TABLE 2. Molecular diagnostic assays for Phytophthora ramorum evaluated in this experimentation

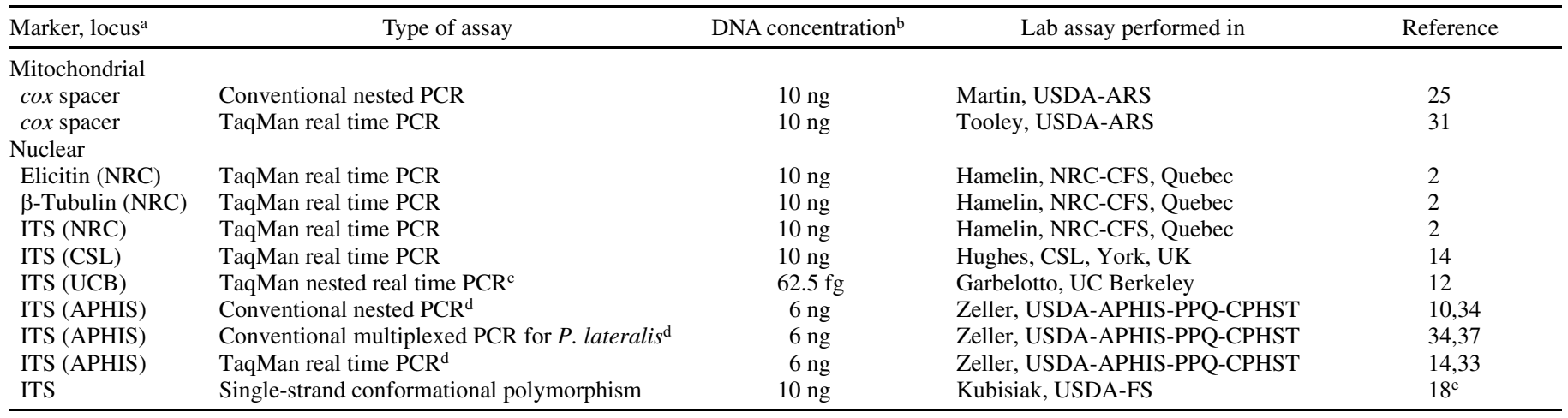

a Diagnostic marker and target locus. ITS = internal transcribed spacer, CSL = Central Science Laboratory, APHIS = Animal and Plant Health Inspection Service, NCR $=$ Natural Resources Canada, UCB $=$ UC Berkeley

${ }^{\mathrm{b}}$ DNA concentrations were provided at $10 \mathrm{ng} / \mu \mathrm{l}$ with the indicated concentrations used in each assay specified.

${ }^{\mathrm{c}}$ In this nested real-time polymerase chain reaction (PCR) the first round is conventional PCR amplification followed by real-time PCR.

${ }^{\mathrm{d}}$ These are the standard United States Department of Agriculture (USDA)-APHIS-approved molecular diagnostic procedures for detection of $P$. ramorum.

e The procedure was modified as indicted in the text to allow for data collection with an automated sequencer. 
isolates that gave false positives were run (for example, $P$. cryptogea was positive in one of two times the sample was run for 1 of 28 isolates) (Tables 3 and 4). All $C_{t}$ were above 34 for the false positives (which is high for $10 \mathrm{ng}$ of DNA), with most above 37 , and many exhibited abnormal amplification kinetics.

Real-time PCR nuclear markers of Bilodeau et al. (2). With the elicitin marker, three false positives were obtained with $P$. arecae (one of two isolates) with inconsistent amplifications for $P$. syringae and a Phytophthora sp. (Tables 3 and 4). With the $\beta$ tubulin marker, four false positives were observed with $P$. hibernalis (one of four isolates), P. palmivora (one of six isolates), and inconsistent amplification one time the assays were run (one of four times two of eight isolates were run) for two isolates of $P$. syringae. With the ITS marker, five false positives were observed with $P$. foliorum (one of four isolates), $P$. hibernalis (one of four isolates), $P$. pseudosyringae (one of four isolates) and $P$. uliginosa (one of two isolates). False positives were also observed for a single isolate of $P$. syringae one of four times the sample was tested. When all three markers were used in combination to make a diagnosis, false positives were only obtained for $P$. hibernalis (one of four isolates, but the $\mathrm{C}_{\mathrm{t}}$ values were high) and $P$. syringae (one of four times the sample was run for one of eight isolates).

CSL ITS TaqMan real-time procedure of Hughes et al. (14). Using the cut-off values described for this procedure (positive below $C_{t}$ of 36 , retest for $C_{t}$ between 36 and 40 , and negative above 40), there were no false positives observed (Tables 3 and 4). Retests were needed for some samples of $P$. cryptogea, $P$. drechsleri, . multivesiculata, $P$. quercina, a Phytophthora sp., $P$. syringae, and $P$. tropicalis, although this was not consistent among isolates of the species or the different times the isolates were run (Table 3). For these retested samples, all $\mathrm{C}_{\mathrm{t}}$ were above 36 , with most close to 39 .
UCB-nested ITS TaqMan real-time procedure of Hayden et al. (12). When amplifications were done with the $1 / 100,000$ dilution of the DNA samples (62.5 fg/amplification for the first round), there were no false positives observed in nested amplifications (Tables 3 and 4). However, some samples were also tested with a higher DNA concentration (1/100 dilution; $62.5 \mathrm{pg} / \mathrm{amplification)}$ and gave false positives for isolates of $P$. alni, $P$. cryptogea, $P$. drechsleri, $P$. multivesiculata, $P$. nicotianae, $P$. quercina, and $P$. syringae (Table 4). Not all species or isolates were tested at this higher DNA concentration.

Approved APHIS diagnostic methods. Samples were run with 6 ng of DNA per amplification.

Conventional nested ITS method (34). In total, 81 false positives were obtained with 35 Phytophthora and Pythium spp. (Tables 3 and 4). Although some of these were the closely related species $P$. foliorum, $P$. hibernalis, and $P$. lateralis, additional species that are more phylogenetically distantly related were amplified as well.

Conventional $P$. lateralis multiplex of Winton and Hansen $(34,37)$. False positives were observed with P. foliorum (four of four isolates) and $P$. hibernalis (four of four isolates). False positives were observed for several other species but the results were not consistent among isolates of the species or the different times these isolates were run. Positive amplifications were observed for $P$. lateralis (three of three isolates), the species for which the assay was developed.

Modified CSL ITS TaqMan real-time (34). Using the cut-off values described for this procedure (positive when $C_{t}<36$ and retest for $\mathrm{C}_{\mathrm{t}}$ between 36 and 40), 35 false positives were observed with $P$. foliorum (all 4 isolates), $P$. hibernalis ( 3 of 4 isolates), $P$. lateralis (2 of 3 isolates), P. porri (1 of 2 isolates), P. pseudosyringae (1 of 4 isolates), P. quercina (1 of 5 isolates), a Phytoph-

TABLE 3. Comparison of the performance of 11 Phytophthora ramorum molecular diagnostic assays when evaluated with a standardized library of culture extracted DNAs and environmental field samples

\begin{tabular}{|c|c|c|c|c|c|c|c|c|c|c|}
\hline \multirow[b]{2}{*}{ Diagnostic marker ${ }^{\mathrm{a}}$} & \multirow[b]{2}{*}{ Type of assay ${ }^{b}$} & \multicolumn{2}{|c|}{ P. ramorum positive } & \multicolumn{2}{|c|}{ P. ramorum negative } & \multirow[b]{2}{*}{ Retest $(\mathrm{E})^{\mathrm{c}}$} & \multirow[b]{2}{*}{ Sens. $^{\mathrm{d}}$} & \multirow[b]{2}{*}{ Spec. ${ }^{\mathrm{e}}$} & \multirow[b]{2}{*}{$P P V^{f}$} & \multirow[b]{2}{*}{$\mathrm{NPV}^{\mathrm{g}}$} \\
\hline & & True (A) & False (B) & False (C) & True (D) & & & & & \\
\hline \multicolumn{11}{|l|}{ Culture-extracted DNA } \\
\hline Nested cox spacer & Conventional (Martin) & 66 & 2 & 1 & 388 & 0 & 98.5 & 99.5 & 97.1 & 99.7 \\
\hline cox Spacer & Real time (Tooley) & 67 & 12 & 0 & 378 & 0 & 100 & 96.9 & 84.8 & 100 \\
\hline Elicitin (NRC) & Real time (Hamelin) & 67 & 3 & 0 & 387 & 0 & 100 & 99.2 & 95.7 & 100 \\
\hline$\beta$-Tubulin (NRC) & Real time (Hamelin) & 67 & 4 & 0 & 386 & 0 & 100 & 99.0 & 94.4 & 100 \\
\hline ITS (NRC) & Real time (Hamelin) & 67 & 5 & 0 & 385 & 0 & 100 & 98.7 & 93.1 & 100 \\
\hline ITS (CSL) & Real time (Hughes) & 66 & 0 & 1 & 379 & 11 & 98.5 & $97.2^{\mathrm{h}}$ & 100 & $96.9^{\mathrm{h}}$ \\
\hline ITS (UCB) & Real time (Garbelotto) & 64 & 0 & 3 & 390 & 0 & 95.5 & 100 & 100 & 99.2 \\
\hline ITS nested (USDA) ${ }^{\mathrm{i}}$ & Conventional (Zeller) & 67 & 81 & 0 & 309 & 0 & 100 & 79.2 & 45.3 & 100 \\
\hline P. lateralis ITS (USDA) ${ }^{\mathrm{i}}$ & Conventional (Zeller) & 67 & 17 & 0 & 373 & 0 & 100 & 95.6 & 79.8 & 100 \\
\hline ITS (USDA) ${ }^{\mathrm{i}}$ & Real time (Zeller) & 67 & 35 & 0 & 311 & 44 & 100 & $79.7^{\mathrm{h}}$ & 65.7 & $87.6^{\mathrm{h}}$ \\
\hline ITS SSCP & SSCP (Kubisiak) & 67 & 0 & 0 & 380 & 0 & 100 & 100 & 100 & 100 \\
\hline \multicolumn{11}{|l|}{ Field samples } \\
\hline Nested cox spacer & Conventional (Martin) & 9 & 0 & 0 & 51 & 0 & 100 & 100 & 100 & 100 \\
\hline cox spacer & Real time (Tooley) & 9 & 0 & 0 & 51 & 0 & 100 & 100 & 100 & 100 \\
\hline Elicitin (NRC) & Real time (Hamelin) & 9 & 0 & 0 & 51 & 0 & 100 & 100 & 100 & 100 \\
\hline$\beta$-Tubulin (NRC) & Real time (Hamelin) & 9 & 1 & 0 & 50 & 0 & 100 & 98.0 & 90 & 100 \\
\hline ITS (NRC) & Real time (Hamelin) & 9 & 0 & 0 & 51 & 0 & 100 & 100 & 100 & 100 \\
\hline ITS (CSL) & Real time (Hughes) & 9 & 0 & 0 & 51 & 0 & 100 & 100 & 100 & 100 \\
\hline ITS (UCB) & Real time (Garbelotto) & 6 & 1 & 3 & 50 & 0 & 66.6 & 98.0 & 85.7 & 94.3 \\
\hline ITS nested (USDA) ${ }^{\mathrm{i}}$ & Conventional (Zeller) & 9 & 9 & 0 & 42 & 0 & 100 & 82.3 & 50.0 & 100 \\
\hline P. lateralis ITS (USDA) ${ }^{\mathrm{i}}$ & Conventional (Zeller) & 9 & 11 & 0 & 40 & 0 & 100 & 78.4 & 45.0 & 100 \\
\hline ITS (USDA) ${ }^{\mathrm{i}}$ & Real time (Zeller) & 9 & 1 & 0 & 37 & 13 & 100 & 72.5 & 90.0 & 74.0 \\
\hline ITS SSCP & SSCP (Kubisiak) & 9 & 0 & 0 & 47 & 4 & 100 & 92.1 & 100 & 92.2 \\
\hline
\end{tabular}

${ }^{a}$ ITS = internal transcribed spacer; CSL = Central Science Laboratory, NCR = Natural Resources Canada, UCB = UC Berkeley.

b SSCP = single-strand conformation polymorphism.

c Samples requiring a retest due to the Ct of the amplification being between 36 and 40 .

${ }^{\mathrm{d}}$ Diagnostic sensitivity $(\%)=100 \times \mathrm{A} /(\mathrm{A}+\mathrm{C})$.

e Diagnostic specificity $(\%)=100 \times \mathrm{D} /(\mathrm{D}+\mathrm{B}+\mathrm{E})$.

${ }^{f} \mathrm{PPV}=$ positive predictive value $(\%)=100 \times \mathrm{A} /(\mathrm{A}+\mathrm{B})$.

g NPV = negative predictive value $(\%)=100 \times \mathrm{D} /(\mathrm{D}+\mathrm{C}+\mathrm{E})$.

${ }^{\mathrm{h}}$ Calculations for these samples included the samples requiring a retest due to the cycle threshold of the amplification being between 36 and 40 .

i These assays were the USDA-Animal and Plant Health Inspection Service-approved diagnostic assays. 
thora spp. (1 of 22 isolates), P. uliginosa (both isolates), and Pythium undulata (one of two times the sample was run) (Tables 3 and 4). False positive were obtained for several other species but this result was not consistent (for example, $P$. alni gave a false positive one of four times the assay was run for one of seven isolates). A number of samples had a $\mathrm{C}_{\mathrm{t}}>36$ and $<40$, which would trigger a retest if they were environmental samples (Table 4).

Results from combining the three APHIS-approved diagnostic methods. By combining the results of the three USDA-APHISapproved assays, false positives would have been identified for $P$. alni (one of four times the sample was run for one of seven isolates), $P$. foliorum (three of four isolates), $P$. hibernalis (three of four isolates), P. lateralis (two of three isolates), P. multi- vesiculata (one of three runs for one isolate and one of two runs for a second of four isolates), P. syringae (one of four runs for one of eight isolates), and P. uliginosa (one of four runs for one of two isolates). Samples rated retest would have been assayed again if they were from plant DNA extractions with the amplicons sequenced if the results were not conclusive.

SSCP analysis. Using the GeneScan polymer or CAP polymer, this procedure correctly identified all $P$. ramorum isolates and there were no false positives observed (data not shown). Given that unique migration types (MTs) were observed for a number of Phytophthora spp., this technique also provided an approach for identification of many species by means tests and cluster analysis of scanline data (Fig. 1). Based on the GeneScan polymer data,

TABLE 4. Results from blind tests evaluating the specificity of the different marker systems when a standard library of DNA from pure cultures of Phytophthora spp. was tested ${ }^{\mathrm{a}}$

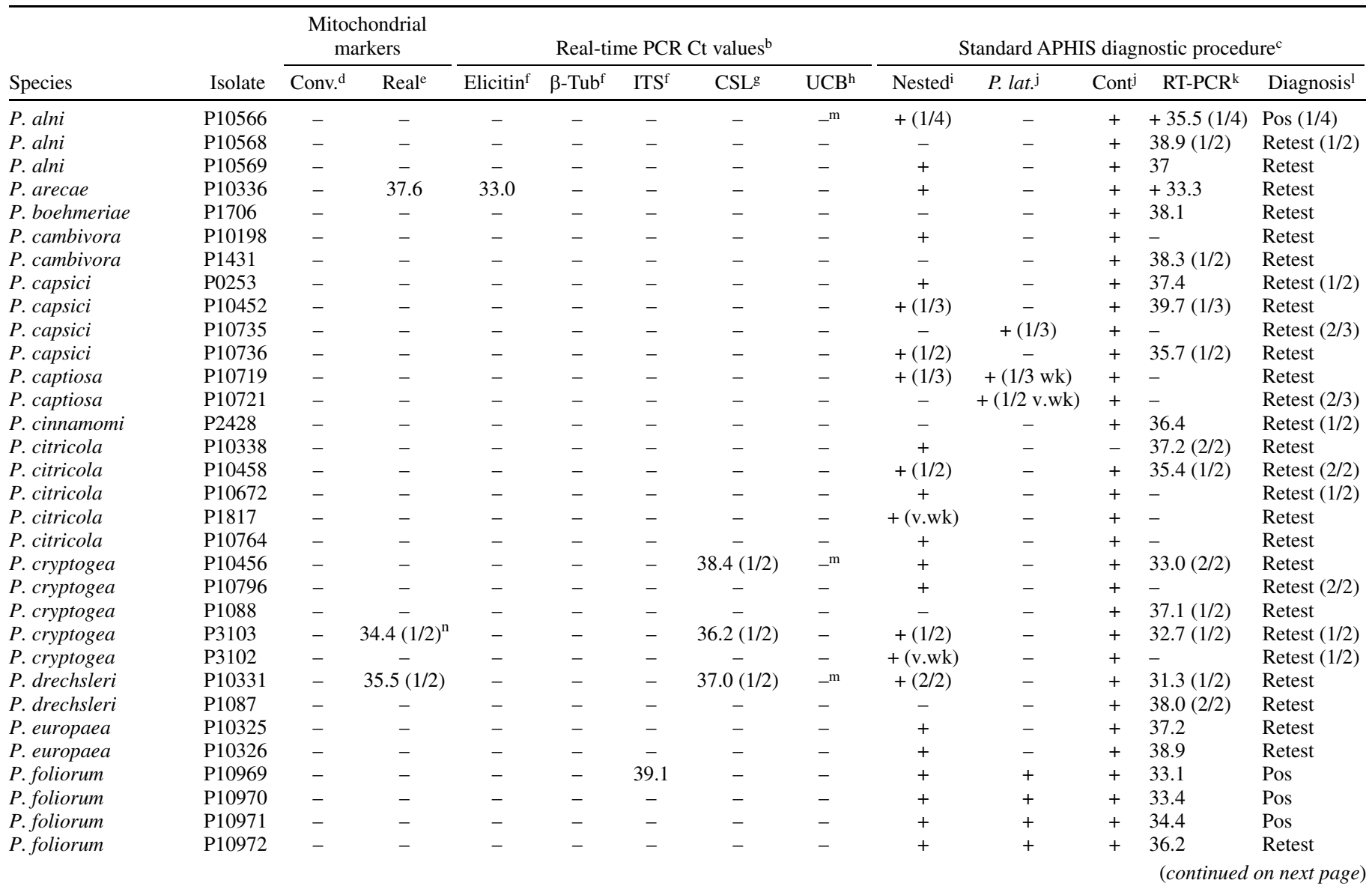

a Samples did not (-) or did (+) amplify. Numbers in parentheses indicated that sample gave the indicated result $x$ of $y$ times $(x / y)$ it was run. ND $=$ not determined. Numbers in the column for the real-time PCR assays are the $\mathrm{C}_{\mathrm{t}}$ values. Isolates from Table 1 that are not listed are either positive for isolates of Phytophthora ramorum or negative for all other species

${ }^{b}$ Polymerase chain reaction $(\mathrm{PCR})$ cycle threshold $\left(\mathrm{C}_{\mathrm{t}}\right)$ values.

${ }^{c}$ APHIS = Animal and Plant Health Inspection Service.

${ }^{\mathrm{d}}$ Conventional nested PCR of Martin et al. (25) tested at a DNA concentration of $10 \mathrm{ng} / \mathrm{amplification}$

${ }^{e}$ Real-time PCR of Tooley et al. (31) with $C_{t}$ values indicated tested at a DNA concentration of $10 \mathrm{ng} /$ amplification.

${ }^{\mathrm{f}}$ Natural Resources Canada (NRC) real-time PCR of Bilodeau et al. (2)tested at a DNA concentration of $10 \mathrm{ng} / \mathrm{amplification}$ with a positive cutoff of $\mathrm{C}_{\mathrm{t}}=40$ for the internal transcribed spacer (ITS) and $\beta$-tubulin $\left(\beta\right.$-Tub) and $\mathrm{C}_{\mathrm{t}}=34$ for the elicitin marker.

${ }^{g}$ Central Science Laboratory (CSL) real-time PCR of Hughes et al. (14) developed at the CSL (York, UK) tested at a DNA concentration of 10 ng amplification; Cont $=$ control.

${ }^{\mathrm{h}}$ UC Berkeley (UCB)-nested TaqMan real-time PCR of Hayden et al. (12) tested at a DNA concentration of 62.5 fg/first round amplification.

${ }^{i}$ Conventional nested PCR of the ITS region (10) following the approved United States Department of Agriculture (USDA)-APHIS-PPQ procedure (34) tested at a DNA concentration of $6 \mathrm{ng} / \mathrm{amplification}$.

j Conventional PCR of the ITS region for detection of P. lateralis with a plant-positive control (37) following the approved USDA-APHIS-PPQ procedure (34) tested at a DNA concentration of $6 \mathrm{ng} /$ amplification. Although it was designed for P. lateralis, this technique amplifies $P$. ramorum as well.

${ }^{k}$ Reverse-transcription (RT)-PCR. Modified real-time PCR of Hughes et al. (14) following the approved USDA-APHIS-PPQ procedure (33) tested at a DNA concentration of $6 \mathrm{ng} / \mathrm{amplification}$.

${ }^{1}$ Pos $=$ positive, neg $=$ negative .

${ }^{\mathrm{m}}$ Samples gave false positive when run at $62.5 \mathrm{pg} / \mathrm{amplification}$ compared with the normal first-round amplification concentration of $62.5 \mathrm{fg}$.

${ }^{\mathrm{n}}$ Sample had an atypical amplification curve that did not look like P. ramorum. 
for the 306 isolates representing 60 taxonomically classified species, 107 unique MTs were observed. Unique MTs within species were identified by obvious scanline differences (i.e., significantly different means or the presence of more than one unique 6-FAM or HEX peak). Of the 107 MTs, 46 could be unambiguously identified based on the migration rate data for only the largest 6-FAM and HEX peaks observed. Fortunately, the MT observed for $P$. ramorum was unique and, hence, these isolates could be unambiguously identified from all other isolates and species. Of the 107 MTs, 61 were found to consist of groups of MTs that were indistinguishable based on only the largest 6FAM and HEX peak data (data not shown). Some of these groupings consisted of more than one MT from within a single species; therefore, the uniqueness of these MTs must be due to the presence of more than one unique 6-FAM or HEX peak. If the presence and migration rate of additional 6-FAM or HEX peaks is taken into consideration, the resolution of the SSCP procedure for identifying unique species and migration types is actually greater than what is presented in Figure 1.

Results from DNA extracted from infected plants from the field. In total, 60 DNA samples extracted from symptomatic plants recovered from the field and processed at the CDFA lab in Sacramento, CA were tested with the different molecular detection systems (Tables 3 and 5). The identification of most of the Phytophthora spp. in each sample was confirmed by sequence analysis of the ITS region used in the described SSCP procedure and the genus-specific amplicon spanning the cox 1 and 2 spacer region (25) (data not shown). The exceptions were samples 17,

TABLE 4. (continued from preceding page)

\begin{tabular}{|c|c|c|c|c|c|c|c|c|c|c|c|c|c|}
\hline \multirow[b]{2}{*}{ Species } & \multirow[b]{2}{*}{ Isolate } & \multicolumn{2}{|c|}{$\begin{array}{c}\text { Mitochondrial } \\
\text { markers }\end{array}$} & \multicolumn{5}{|c|}{ Real-time PCR Ct values ${ }^{b}$} & \multicolumn{5}{|c|}{ Standard APHIS diagnostic procedure ${ }^{\mathrm{c}}$} \\
\hline & & Conv. $^{\mathrm{d}}$ & Real $^{\mathrm{e}}$ & Elicitin $^{\mathrm{f}}$ & $\beta-\mathrm{Tub}^{\mathrm{f}}$ & ITS $^{f}$ & $\mathrm{CSL}^{\mathrm{g}}$ & $\mathrm{UCB}^{\mathrm{h}}$ & Nested $^{\mathrm{i}}$ & P. lat. $^{\mathrm{j}}$ & Cont $^{\mathrm{j}}$ & RT-PCR ${ }^{k}$ & Diagnosis ${ }^{1}$ \\
\hline P. gonapodyides & P10337 & - & - & - & - & - & - & - & - & - & + & $38.0(1 / 2)$ & Retest \\
\hline P. gonapodyides & P10679 & - & - & - & - & - & - & - & $+(1 / 3)$ & - & + & - & Retest (1/2) \\
\hline P. heveae & P1102 & - & - & - & - & - & - & - & - & - & + & 38.4 & Retest (1/3) \\
\hline P. hibernalis & P3822 & - & - & - & - & - & - & - & $+(1 / 3)$ & $+(3 / 3)$ & + & $37.9(3 / 3)$ & Retest \\
\hline P. hibernalis & P6871 & - & - & - & - & - & - & - & + & + & + & 35.5 & Pos \\
\hline P. hibernalis & P0647 & - & - & - & - & - & - & - & + & + & + & 36.7 & Pos \\
\hline P. hibernalis & P10680 & - & - & 36.0 & 37.4 & 34.1 & - & - & + & + & + & 33.4 & Pos \\
\hline P. idaei & P6767 & - & - & - & - & - & - & - & + & - & + & 38.1 & Retest \\
\hline P. infestans & P10253 & - & - & - & - & - & - & - & + & - & + & - & Retest \\
\hline P. inflata & P10341 & - & - & - & - & - & - & - & $+(1 / 2)$ & - & + & $38.8(2 / 2)$ & Retest \\
\hline P. lateralis & P1728 & - & - & - & - & - & - & - & - & $+(2 / 2)$ & + & $34.8(1 / 2)$ & Retest (2/2) \\
\hline P. lateralis & P3888 & - & - & - & - & - & - & - & $+(2 / 2)$ & $+(2 / 2)$ & + & $32.9(2 / 2)$ & $\operatorname{Pos}(2 / 2)$ \\
\hline P. lateralis & P10177 & - & - & - & - & - & - & - & + & + & + & 33.6 & Pos \\
\hline P. macrochlamydospora & P10263 & - & - & - & - & - & - & - & + & - & + & - & Retest \\
\hline P. macrochlamydospora & P8017 & - & - & - & - & - & - & - & - & - & + & $38.0(1 / 2)$ & Retest (1/2) \\
\hline P. megasperma & P10340 & - & - & - & - & - & - & - & $+(2 / 3)$ & - & - & $37.8(2 / 3)$ & Retest (3/3) \\
\hline P. megasperma & P6046 & - & - & - & - & - & - & - & + & - & + & 37.8 & Retest \\
\hline P. mirabilis & P3007 & - & - & - & - & - & - & - & - & - & + & $37.4(1 / 2)$ & Retest (1/2) \\
\hline P. mirabilis & P3008 & - & - & - & - & - & - & - & - & - & + & 38.3 & Retest \\
\hline P. multivesiculata & P10327 & - & - & - & - & - & - & $-{ }^{\mathrm{m}}$ & $+(2 / 3)$ & $+(1 / 3 w k)$ & + & $33.6(2 / 3)$ & $\begin{array}{l}\text { Pos }(1 / 3) \\
\quad \text { retest }\end{array}$ \\
\hline P. multivesiculata & P10525 & - & $39.5(1 / 2)$ & - & - & - & $39.3(2 / 2)$ & $-^{\mathrm{m}}$ & $+(2 / 2)$ & $+(1 / 2 w k)$ & + & 33.8 & $\begin{array}{l}\text { Pos }(1 / 2) \\
\text { retest }\end{array}$ \\
\hline P. nicotianae & P10362 & - & - & $35.1(1 / 2)$ & - & - & - & - & - & - & + & - & Neg \\
\hline P. nicotianae & P10451 & - & - & - & - & - & - & $-^{\mathrm{m}}$ & $+(2 / 2)$ & - & + & $37.6(2 / 2)$ & Retest $(2 / 2)$ \\
\hline P. nicotianae & P10802 & - & - & - & - & - & - & - & - & - & + & 38.4 & Retest \\
\hline P. porri & P10728 & + & 36 & - & - & - & - & - & + & - & + & 32.0 & Retest \\
\hline P. pseudotsugae & P10339 & - & - & - & - & - & - & - & $1 / 3+$ & - & - & $39.1(1 / 3)$ & Retest (1/3) \\
\hline P. pseudotsugae & P10218 & - & - & - & - & - & - & - & + & - & + & - & Retest \\
\hline P. pseudosyringae & P10444 & - & - & 37 & - & 35.8 & - & - & + & - & + & 34.4 & Retest \\
\hline P. psychrophila & P10433 & - & - & - & - & - & - & - & - & - & + & 38.8 & Retest \\
\hline P. quercina & P10334 & - & $38.5(2 / 2)$ & - & - & - & $37.8(2 / 2)$ & $-^{\mathrm{m}}$ & $+(2 / 2)$ & - & + & $34.2(2 / 2)$ & Neg \\
\hline P. palmivora & P10769 & - & - & - & 38.1 & - & - & - & - & - & + & - & Neg \\
\hline P. ramorum & P10318 & $+(2 / 3)$ & + & + & + & + & + & $+(2 / 3)$ & + & + & + & 19.3 & Pos \\
\hline P. ramorum & P10303 & + & + & + & + & + & $+(1 / 2)$ & $-(2 / 2)$ & + & + & + & 28.3 & Pos \\
\hline P. richardiae & P10335 & - & - & - & - & - & - & - & + & - & + & 37.1 & Retest \\
\hline P. richardiae & P10811 & - & $37.2^{\mathrm{n}}$ & - & - & - & - & - & + & - & + & 35.9 & Retest \\
\hline P. richardiae & P7788 & - & - & - & - & - & - & - & $+(1 / 2)$ & - & + & $37.7(1 / 2)$ & Retest (1/2) \\
\hline P. sojae & P10705 & - & - & - & - & - & - & - & + & - & + & 36.5 & Retest \\
\hline Phytophthora sp. & P10707 & - & $38.6(1 / 2)$ & $32.8(1 / 2)$ & - & - & $39.5(1 / 2)$ & - & $+(1 / 2)$ & - & + & $32.2(1 / 2)$ & Retest (1/2) \\
\hline Phytophthora sp. & P10708 & - & - & - & - & - & - & - & $+(1 / 2 w k)$ & - & + & - & Retest (1/2) \\
\hline Phytophthora sp. & P10364 & - & - & - & - & - & - & - & + & - & + & 35.1 & Retest \\
\hline Phytophthora sp. & P10670 & - & - & - & - & - & - & - & $+(2 / 3)$ & - & + & $37.8(2 / 3)$ & Retest (2/3) \\
\hline Phytophthora sp. & P7902 & - & - & - & - & - & - & - & - & - & + & 38.6 & Retest \\
\hline Phytophthora sp. & P7907 & - & - & - & - & - & - & - & $+(\mathrm{v} . \mathrm{wk})$ & - & + & - & Retest \\
\hline P. syringae & P10330 & - & - & $34.6(1 / 4)$ & $38.2(1 / 4)$ & - & $37.9(1 / 5)$ & $-^{\mathrm{m}}$ & $+(4 / 4)$ & - & + & $37.8(1 / 4)$ & Retest (4/4) \\
\hline P. syringae & P10332 & - & $36.4(1 / 4)^{j}$ & $34.0(1 / 4)$ & $33.7(1 / 4)$ & $37.9(1 / 4)$ & $39.2(1 / 3)$ & - & $+(4 / 4)$ & $+(1 / 4 w k)$ & + & $33.3(2 / 4)$ & $\begin{array}{l}\text { Retest (3/4), } \\
\quad+(1 / 4)\end{array}$ \\
\hline P. syringae & P0649 & - & - & - & - & - & - & - & wk + & $+(w k)$ & + & - & Retest \\
\hline P. tropicalis & P10329 & - & - & $35.4(1 / 3)$ & - & - & $39.9(1 / 3)$ & - & $+(3 / 3)$ & - & + & $36.5(3 / 3)$ & Retest (3/3) \\
\hline P. uliginosa & P10328 & $+(1 / 3)$ & $37.7(2 / 4)$ & - & - & - & - & - & $+(3 / 4)$ & - & + & $35.3(4 / 4)$ & $\begin{array}{l}\text { Retest (3/4), } \\
+(1 / 4)\end{array}$ \\
\hline P. uliginosa & P10413 & ND & - & - & - & 36.1 & - & - & + & - & + & 35.6 & Retest \\
\hline Pythium undulata & P10342 & - & - & - & - & - & - & - & $+(2 / 2)$ & - & + & $35.1(1 / 2)$ & Retest (2/2) \\
\hline Pythium sp. & P10757 & - & 39.7 & - & - & - & - & - & + & - & + & 36.6 & Retest \\
\hline
\end{tabular}


$19,25,26$, and 52, which had multiple templates amplified that precluded sequencing unless the templates were cloned (likely due to two or more Phytophthora spp. present in the infected tissue). All the diagnostic assays correctly identified samples where $P$. ramorum was present, with the exception of the UCBnested ITS TaqMan real-time amplification of Hayden et al. (12) for samples 4,5 , and 8 . False positives were not observed for the conventional (25) or real-time PCR (31) mitochondrial cox 1 and 2 spacer diagnostic procedures, the CSL ITS TaqMan real-time PCR assay of Hughes et al. (14), or the assays of Bilodeau et al. (2) when the results of the three tests were combined. However, when looked at individually, the $\beta$-tubulin marker had one false positive (the elicitin marker had two species with a $C_{t}$ of 36 and 38 , but a cut-off of 34 cycles is currently used for this marker). The UCB-nested ITS TaqMan real-time procedure of Hayden et al. (12) had one false positive for a sample with $P$. hibernalis. The USDA-APHIS-approved techniques also had several false positives; the conventional nested ITS procedure $(10,34)$ had 9 samples that were not $P$. ramorum with inconclusive results (primarily $P$. foliorum and $P$. hibernalis) whereas, for the conventional multiplexed $P$. lateralis PCR marker of Winton and Hansen (37), there were 10 false positives (primarily $P$. foliorum and $P$.

A

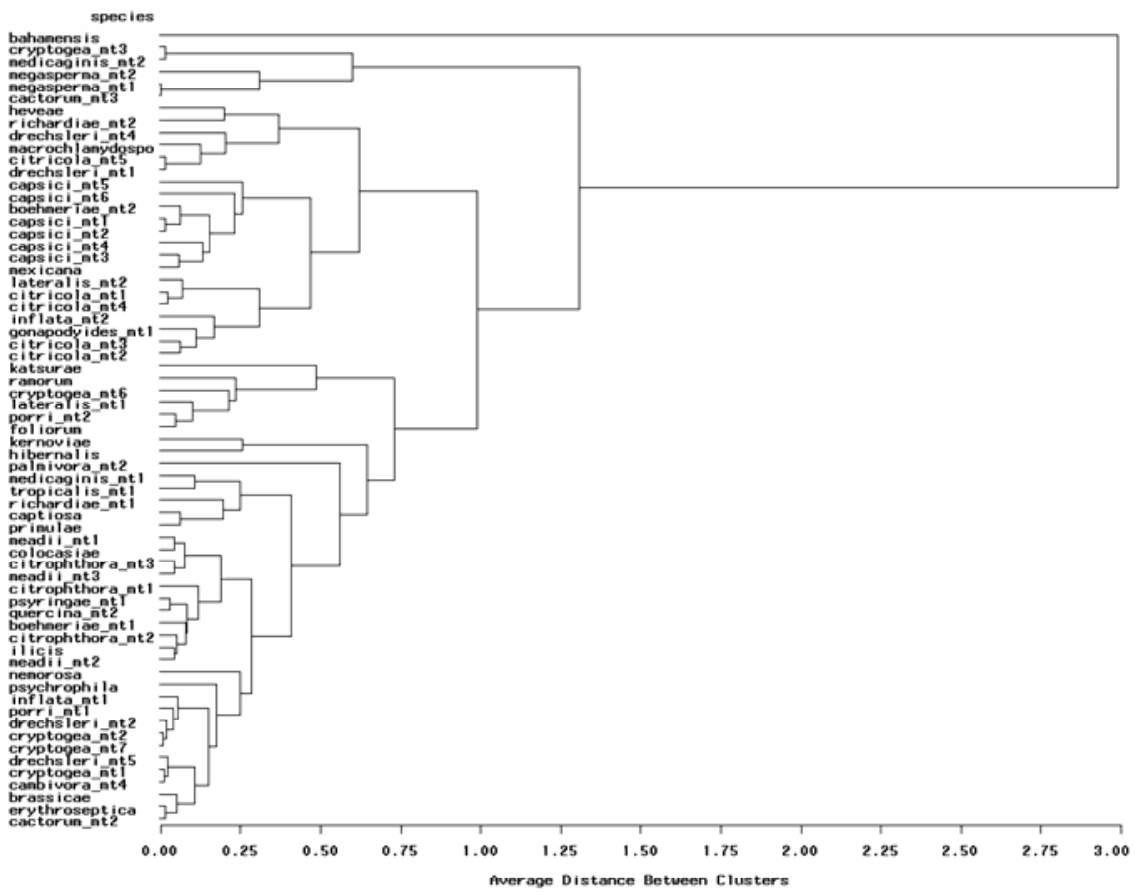

B

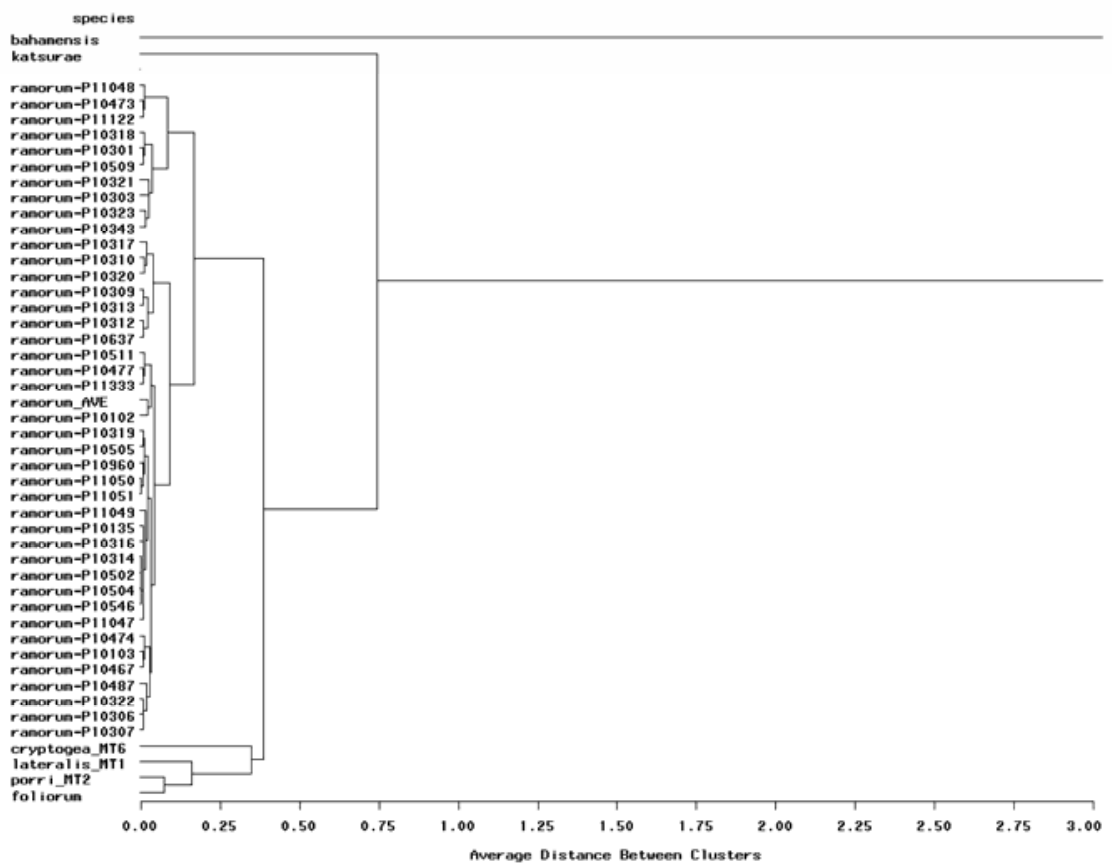

Fig. 1. Unweighted pair group method with arithmetic means cluster analysis of scanline data for single-strand conformation polymorphism analysis collected on a fluorescent-based capillary DNA sequencer for A, showing a number of Phytophthora spp. and migration types (mt) and B, showing intraspecific scanline variation for Phytophthora ramorum. 
hibernalis). The USDA-APHIS-PPQ-approved modified CSL ITS TaqMan real-time procedure of Hughes et al. $(14,33)$ had eight samples with $C_{t}$ values high enough to require a retest and one sample with $P$. hibernalis that was a false positive. When all three assays were used together to make a diagnosis, six samples (primarily $P$. foliorum and $P$. hibernalis) were classified as negative; however, based on the results for some of the assays, the approved USDA-APHIS-PPQ procedures would have required sequencing or additional secondary diagnostics to confirm this assessment. The results for three samples with $P$. hibernalis were inconclusive and the approved USDA-APHIS-PPQ procedures would have required sequencing or additional secondary diagnostics to reach a diagnosis. The SSCP analysis correctly identified all $P$. $r a$ morum samples; however, there was some uncertainty for four of five $P$. citrophthora samples. In addition to single predominant 6FAM and HEX peaks, these three samples harbored minor 6-FAM and HEX peaks that were contained within the $95 \%$ confidence intervals expected for $P$. ramorum. Thus, these samples were flagged as being suspect for the pathogen. This technique also correctly identified many of the other Phytophthora spp. that were in the samples to a species level although, for some, this identification was only to the level of a group of possible species.

Analysis of sensitivity and specificity of the diagnostic procedures. For culture-extracted DNA, the diagnostic sensitivity (the proportion of true positive correctly identified) was $100 \%$ for seven of the assays, $98.5 \%$ for two assays (conventional nested cox spacer and CSL ITS TaqMan real time), and $95.5 \%$ for the UCB-nested ITS TaqMan real-time assay (Table 3). Diagnostic specificity (the proportion of true negatives correctly identified) were $>95 \%$ for all assays except the APHIS-approved conventional nested ITS assay and the modified CSL ITS TaqMan realtime PCR assay (79.2 and 79.7\%, respectively). As a reflection of the numbers of false positives, the PPV (proportion of tests with true positives correctly identified) were $>93 \%$ for all assays except the cox spacer real-time assay $(84.8 \%)$, APHIS-approved conventional ITS nested $(45.3 \%), P$. lateralis conventional (79.8\%), and modified CSL ITS TaqMan real-time PCR assay (65.7\%). The values for the NPV (proportion of tests where a negative is correctly identified) were all $>99.2 \%$ except for the two assays where samples were classified as retest (the CSL ITS TaqMan real-time assay was $96.9 \%$ while the APHIS-approved modification of this assay was $87.6 \%$ ).

For the analysis of field samples, the values for diagnostic sensitivity were $100 \%$ for all assays except the UCB-nested ITS TaqMan real-time assay, where three of the nine $P$. ramorum positives were not correctly identified (Table 3). Values of $100 \%$ were observed for diagnostic sensitivity, diagnostic specificity, PPV, and NPV for the conventional nested cox spacer assay, the real-time cox spacer assay, the elicitin and ITS assay of Bilodeau et al. (2), and the CSL ITS TaqMan real-time procedure. Due to the presence of false positives, the PPV was reduced for the remaining assays; in particular, the APHIS-approved conventional ITS nested assay and the conventional multiplexed $P$. lateralis PCR marker of Winton and Hansen (37) (50 and 45\%, respectively).

\section{DISCUSSION}

With two exceptions, all assays correctly identified 47 isolates of $P$. ramorum collected from the geographic range of this species. The CSL ITS TaqMan real-time ITS procedures of Hughes et al. (14) and UCB-nested ITS TaqMan technique of Hayden et al. (12) were inconsistent in detection of one and two isolates, respectively. The existence of potential false positives was evaluated by blind testing of a standardized library of DNA extracted from pure cultures. The concentration that was tested in all but the UCB-nested ITS TaqMan real-time assay, 6 to $10 \mathrm{ng} / \mu \mathrm{l}$, was higher than would be encountered in DNA extractions from infected plant tissue and may have triggered false positives in some of the optimized diagnostic assays; however, this level was selected to provide a rigorous test of specificity (primarily for real-time PCR procedures). The fewest false positives were observed with the SSCP analysis, where none were obtained. This was followed by the conventional nested PCR mitochondrial marker spanning the cox 1 and 2 spacer region (25); the $\beta$-tubulin, ITS, and elicitin real-time PCR procedures of Bilodeau et al. (2); and the real-time PCR cox spacer marker of Tooley et al. (31). No false positives were obtained for the CSL ITS real-time PCR procedure of Hughes et al. (14), but there were nine samples with a $C_{t}$ between 36 and 40 that were classified as a retest. The modification of the CSL procedure for the approved USDAAPHIS-PPQ procedure (33) had additional samples that required retesting as well as several false positives, primarily the closely related species $P$. foliorum, $P$. hibernalis, and $P$. lateralis. The USDA-APHIS-PPQ multiplex PCR procedure of Winton and Hansen for $P$. lateralis $(34,37)$ also had positives for these species, as did the conventional nested ITS procedure $(10,34)$. Although no false positives were observed for the UCB-nested ITS TaqMan real-time PCR technique of Hayden et al. (12), at 62.5 fg this assay used a much lower target DNA concentration than the other assays; when $62.5 \mathrm{pg} / \mu \mathrm{l}$ was used for a limited number of species some false positives were encountered.

False positives that vary from run to run could be due to inconsistent amplification of nontarget sequences, cross contamination, or mislabeling of tubes; however, sequencing of amplicons would be needed to confirm which was occurring. Differences in false positives were also observed for the mitochondrial marker systems based on the spacer region between the cox 1 and 2 genes for the conventional and real-time PCR techniques even though the $P$. ramorum-specific primer pair was the same $(25,31)$. This is likely due to the greater sensitivity of TaqMan real-time PCR and the high concentration of the target DNA used in this amplification. As noted above, the 6 to $10 \mathrm{ng}$ of template DNA that was used in all but one of the assays is greater than would be encountered in DNA extracted from infected plant tissue. For example, using the cox spacer region TaqMan real-time PCR assay, Tooley et al. (31) obtained $\mathrm{C}_{\mathrm{t}}$ values of 28 and 40 for DNA extracted from infected rhododendron leaves that corresponded to $21 \mathrm{pg}$ and 13 fg of target DNA, respectively. Using the QuickPick Plant DNA kit from Bio-Nobile, Tomlinson et al. (30) reported that 10 to $100 \mathrm{pg}$ of target DNA was recovered from 15 to $25 \mathrm{mg}$ of symptomatic rhododendron leaf material. From extrapolation of $\mathrm{C}_{\mathrm{t}}$ values from standard curves for 74 field samples extracted from a variety of hosts following USDA-APHIS-PPQ-approved procedures (32), the USDA-APHIS-PPQ-NPGBL concluded that the mean concentration of $P$. ramorum DNA was $50 \mathrm{pg} / \mu \mathrm{l}$ and was rarely found at $>2 \mathrm{ng} / \mu \mathrm{l}$ or $<100 \mathrm{fg} / \mu \mathrm{l}$ (K. Zeller, personal communication). Thus, the large amount of template DNA used in these assays provided a rigorous test of specificity and probably overestimates the number of false positives that would be obtained from field samples. A dilution series of purified DNA for each false-positive testing species should be evaluated to determine the concentration threshold for amplification and then compared with pathogen DNA concentrations commonly encountered in infected tissue.

Rather then rely on a single assay to determine whether $P$. ramorum was present, two labs used a combination of markers. The advantage of doing this is clearly demonstrated from reviewing the results obtained when using the three USDA-APHISPPQ-approved procedures for P. ramorum detection $(33,34)$. Use of the conventional nested PCR procedure as a stand-alone procedure resulted in the highest number of false positives of all the assays evaluated, whereas combining this with the other two USDA-APHIS-approved assays (which is the standard practice) reduces false positives primarily to the phylogenetically closely related species $P$. foliorum, $P$. hibernalis, and $P$. lateralis. Using a 
combination of tests that target different genetic loci further reduced the number of false positives. With the exception of one isolate of $P$. hibernalis that amplified with the elicitin assay, the combined results of the ITS, $\beta$-tubulin, and elicitin markers of Bilodeau et al. (2) did not have false positives. Combining diagnostic assays has the added advantage of reducing both false positive and false negative results. False negative results in diagnostic assays can result in unwanted establishment of an exotic pathogen whereas false positive results can result in unnecessary regulatory action and crop destruction.

Field samples from forest ecosystems and ornamental nurseries were also evaluated in this study, with all nine $P$. ramorumpositive samples correctly identified in all but one method; the UCB-nested ITS TaqMan real-time assay of Hayden et al. (12) had false negatives for three samples. Interestingly, these samples were positive using the SYBR green assay of Hayden et al. (13) in the same laboratory (M. Garbelotto, unpublished), which suggests that operator error may be responsible for the results of the TaqMan assay. No false positives were observed with the other techniques, with the exception of the real-time $\beta$-tubulin and elicitin markers of Bilodeau et al. (2), each of which had one false positive but for different samples. When all three markers of Bilodeau et al. (2) were used together, there were no false positives. Likewise, when the three USDA-APHIS-PPQ-approved assays $(33,34)$ were used together, there were no false positives but three $P$. hibernalis samples were inconclusive and required additional testing. When the three assays were used individually, several false positives were observed.

Given the quarantine nature of $P$. ramorum, it is important that the diagnostic methods used for pathogen detection are highly specific. When using culture-purified DNA, the diagnostic sensitivity for the evaluated assays was high $(100 \%$ for all but three assays, with the UCB-nested ITS TaqMan real-time assay the lowest at $95.5 \%$ ). Similar results were observed when field samples were the source of template DNA (the diagnostic sensitivity was $100 \%$ for all but one of the assays). Because this diagnostic value is a reflection of the proportion of true positives correctly identified by the diagnostic assay, it is desirable to have a value as close to $100 \%$ as possible to prevent pathogen movement through false negatives. Diagnostic specificity is also important because it is a measure of true negatives correctly identified by the assay; the higher this value, the fewer false-positive samples are encountered. For culture-extracted DNA, most of the assays had values ranging between 96.9 and $100 \%$, with lower values for the APHIS-approved conventional nested ITS $(79.2 \%)$ and the modified CSL ITS TaqMan real-time procedures (79.7\%); similar

TABLE 5. Results for 11 diagnostic assays for detection of Phytophthora ramorum from blind analysis of plant samples collected from the field and DNA extracted according to the approved United States Department of Agriculture-Animal and Plant Health Inspection Service (USDA-APHIS)-PPQ protocol at the California Department of Food and Agriculture ${ }^{\mathrm{a}}$

\begin{tabular}{|c|c|c|c|c|c|c|c|c|c|c|c|c|c|c|c|}
\hline$\underline{\text { Sample, host }}$ & Species $^{\mathrm{b}}$ & \multicolumn{2}{|c|}{$\begin{array}{l}\text { Mitochondri } \\
\text { al marker }\end{array}$} & \multicolumn{6}{|c|}{$\begin{array}{l}\text { Real-time } \\
\text { polymerase chain reaction }(\mathrm{PCR})\end{array}$} & \multicolumn{6}{|c|}{$\begin{array}{c}\text { Standard USDA-APHIS-PPQ } \\
\text { diagnostic procedure }\end{array}$} \\
\hline 1 Camellia sasanqua & ramorum & + & 29.2 & + & 26.5 & 28.5 & 25.6 & 30.8 & 18.6 & + & + & + & 21.1 & Pos & + \\
\hline 3 Camellia japonica & ramorum & + & 25.2 & + & 22.4 & 26.0 & 22.3 & 27.0 & 18.6 & + & + & + & 18.0 & Pos & + \\
\hline 4 Camellia japonica & ramorum & + & 31.1 & + & 26.1 & 28.6 & 25.4 & 29.2 & $\mathrm{~m}$ & + & + & + & 20.5 & Pos & + \\
\hline 5 Camellia japonica & ramorum & + & 30.9 & + & 27.8 & 30.9 & 27.8 & 32.5 & $\mathrm{~m}$ & + & + & + & 22.9 & Pos & + \\
\hline 9 Umbellularia californica & ramorum & + & 31.2 & + & 27.9 & 31.0 & 28.0 & 31.9 & 20.9 & + & + & + & 23.2 & Pos & + \\
\hline 10 Rhamnus californica & cactorum & - & - & - & - & - & - & - & - & - & - & + & - & Neg & - \\
\hline 11 Rhamnus californica & cactorum & - & - & - & - & - & - & - & - & - & - & + & - & Neg & - \\
\hline 12 Magnolia sp. & citricola & - & - & - & - & - &,- 42.5 & - & - & - & - & + & 39.5 & Neg & - \\
\hline 13 Rhododendron sp. (azalea) & citricola & - & - & - & - & - & - & - & - & \pm & - & + & $39.7^{\mathrm{n}}$ & $\mathrm{Neg}$ & - \\
\hline 14 Rhododendron sp. & citricola & - & - & - & - & - & - & - & - & - & - & + & - & Neg & - \\
\hline
\end{tabular}

a Samples did not (-) or did (+) amplify; \pm indicates an inconclusive diagnosis, $w=$ weak. Numbers in the column for the real-time PCR assays are the $\mathrm{C}_{\mathrm{t}}$ values. For the SSCP, a + indicates a P. ramorum banding pattern.

${ }^{\mathrm{b}}$ Phytophthora spp. identification was confirmed by culturing of the pathogen at the time of DNA extraction as well as DNA sequence analysis of the internal transcribed spacer (ITS) amplicon generate in the single-strand conformation polymorphism (SSCP) analysis and the genus-specific amplicon spanning the spacer region between the coxl and cox 2 gene.

${ }^{c}$ Conventional nested PCR of Martin et al. (25).

${ }^{\mathrm{d}}$ Real-time PCR of Tooley et al. (31) with a positive cutoff of cycle threshold $\left(\mathrm{C}_{\mathrm{t}}\right)=40$

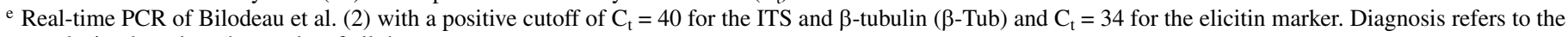
conclusion based on the results of all three tests.

${ }^{\mathrm{f}}$ Central Science Laboratory (CSL) real-time PCR of Hughes et al. (14) developed at the CSL, York, UK with a with a positive cutoff of $\mathrm{C}_{\mathrm{t}}=36$ and retesting between $\mathrm{C}_{\mathrm{t}} 36$ and 40 .

g UC Berkeley (UCB)-nested TaqMan real-time PCR of Hayden et al. (12) with a positive cutoff of $\mathrm{C}_{\mathrm{t}}=40$.

${ }^{\mathrm{h}}$ Conventional nested PCR of the ITS region (10) following the approved APHIS procedure (34).

${ }^{\mathrm{i}}$ Conventional multiplexed PCR of the ITS region for P. lateralis with a plant positive control (37) following the approved USDA-APHIS-PPQ procedure (34). While it was designed for $P$. lateralis this technique amplifies $P$. ramorum as well.

j Modified CSL real-time PCR of Hughes et al. (14) following the approved USDA-APHIS-PPQ procedure (33).

k Diagnosis: Pos $=$ positive, Neg $=$ negative, and Incon $=$ inconclusive .

${ }^{1}$ SSCP procedure of Kong et al. $(18,19)$ run on a fluorescent-based capillary DNA sequencer under conditions noted in the Materials and Methods.

${ }^{\mathrm{m}}$ Samples inconclusive for $P$. ramorum using USDA-APHIS procedures would have required sequencing or additional secondary diagnostics to reach a diagnosis.

${ }^{n}$ Only one of two runs had a $C_{t}$ value, which is indicated.

o Samples negative for $P$. ramorum, but APHIS procedures would have required sequencing or additional secondary diagnostics confirm this assessment.

p Sample run three times with average $C_{t}$ of $48.7,43.2$, and $<60$.

${ }^{\mathrm{q}}$ Species identification from California Department of Food and Agriculture analysis, but no Phytophthora spp. were detected in SSCP analysis and the Phytophthora genus-specific amplicon of Martin et al. (25).

r Samples were negative with the nested TaqMan procedure but were positive with the nested SYBR green technique (13). 
results were observed when field samples were examined. Whereas both these APHIS-approved assays had false positives (more so with the conventional nested ITS procedure), the relatively high number of samples requiring a retest with the modified CSL ITS TaqMan real-time procedure contributed to the lower diagnostic specificity value. The proportion of samples with positive results that correctly identified the pathogen (PPV) was also high for most assays, with the lowest values observed for the APHIS-approved conventional nested ITS procedure. Finally, the proportion of the negative test results that are correctly identified by the diagnostic assay (NPV) was high for all methods for both purified-culture DNA and field samples. The only exception is for the APHIS-approved modified CSL ITS TaqMan real-time procedure, which was lower due to the number of samples rated as retest.

The diagnostic values for the CSL ITS TaqMan real-time procedure were also examined in Kox et al. (20) in their evaluation of 148 rhododendron field samples. The values they obtained were similar to those observed in this study, with the exception that greater values were obtained in the current study for diagnostic sensitivity (98.5 and $100 \%$ for the culture-extracted DNA and field samples, respectively, compared with 83.8\%) and NPV (100 and $100 \%$ for the culture-extracted DNA and field samples, respectively, compared with $87.9 \%$ ). The higher percentage of $P$. ramorum-positive samples included in their study (42\%) may have contributed to these differences. Although the UCB ITS TaqMan real-time procedure was also examined by Kox et al. (20), it was not the nested procedure that was used in this current investigation (the internal nested primers were used for a single round of amplification).

Comparison of results obtained with the APHIS-approved conventional nested ITS procedure and their modified CSL TaqMan real-time procedure have been reported previously by Bulluck et al. (4). In the analysis of 300 camellia samples, $34.6 \%$ of the samples rated positive using the APHIS-approved conventional nested ITS procedure were negative with the APHIS-approved modified CSL ITS TaqMan real-time assay (both assays were in agreement for the remaining $65.4 \%$ ). Likewise, there was a greater level of pathogen recovery from tissue for samples rated positive with the APHIS-approved modified CSL ITS TaqMan real-time assay (76.5\% of the PCR positives) than the APHISapproved conventional nested ITS procedure $54.2 \%$ of the PCR positives). Whether this discrepancy in positive results is due to the greater sensitivity of the conventional ITS nested procedure being able to detect low levels of the pathogen or lesions where the pathogen was no longer viable rather than true false positives is unknown.

TABLE 5. (continued from preceding page)

\begin{tabular}{|c|c|c|c|c|c|c|c|c|c|c|c|c|c|c|c|}
\hline \multirow[b]{2}{*}{ Sample, host } & \multirow[b]{2}{*}{ Species $^{b}$} & \multicolumn{2}{|c|}{$\begin{array}{l}\text { Mitochondrial } \\
\text { marker }\end{array}$} & \multicolumn{6}{|c|}{$\begin{array}{c}\text { Real-time } \\
\text { polymerase chain reaction (PCR) }\end{array}$} & \multicolumn{6}{|c|}{$\begin{array}{c}\text { Standard USDA-APHIS-PPQ } \\
\text { diagnostic procedure }\end{array}$} \\
\hline & & Conve & Real $^{\mathrm{d}}$ & $\operatorname{Diag}^{\mathrm{e}}$ & Elicitin ${ }^{\mathrm{e}}$ & $\beta-\mathrm{Tub}^{\mathrm{e}}$ & ITS $^{\mathrm{e}}$ & $\mathrm{CSL}^{\mathrm{f}}$ & $\mathrm{UCB}^{\mathrm{g}}$ & $\mathrm{Nest}^{\mathrm{h}}$ & P. $l a t^{\mathrm{i}}$ & Cont $^{\mathrm{i}}$ & $\mathrm{RT}^{-P C R}{ }^{\mathrm{j}}$ & Diagk $^{k}$ & $\mathrm{SSCP}^{\mathrm{l}}$ \\
\hline 17 Archtostaphylous edmundsii & citrophthora & - & - & - & - & - & - & - & - & - & - & + & - & Neg & \pm \\
\hline 18 Archtostaphylous sp. & citrophthora & - & - & - & - & - & - & - & - & - & - & + & - & Neg & \pm \\
\hline 19 Camellia japonica & citrophthora & - & - & - & - & - &,- 42.2 & - & - & \pm & - & + & 38.8 & Neg & \pm \\
\hline 20 Pieris japonica & citrophthora & - & - & - & - & - & - & - & - & - & - & + & - & Neg & - \\
\hline 21 Umbellularia californica & citrophthora & - & - & - &,- 38.0 & - & - & - & - & - & - & + & - & Neg & \pm \\
\hline 22 Rhododendron sp. (azalea) & foliorum & - & - & - & - & - & - & - & - & - & + & + &,- 43.6 & $\mathrm{Neg}^{\mathrm{o}}$ & - \\
\hline 23 Rhododendron sp. (azalea) & foliorum & - & - & - &,- 41.6 & - & - & - & - & \pm & + & + & 37.4 & $\mathrm{Neg}^{\mathrm{o}}$ & - \\
\hline 24 Rhododendron sp. (azalea) & foliorum & - & - & - & - & - & - & - & - & \pm & + & + & 40.3 & Negp & - \\
\hline 25 Arbutus unedo & gonapodyides & - & - & - & - & - &,- 44.0 & - & - & - & - & + & - & $\mathrm{Neg}$ & - \\
\hline 26 Arbutus unedo & hibernalis & - & - & - & - & - & - & - & - & - & - & + & - & $\mathrm{Neg}$ & - \\
\hline 27 Photinia sp. & hibernalis & - &,- 42.2 & - & - & - &,- 40.9 & - & 24.5 & \pm & + & + & 36.7 & Incon $^{\mathrm{m}}$ & - \\
\hline 28 Photinia sp. & hibernalis & - &,- 44.2 & - &,- 36.0 & - &,- 41.3 & - & - & \pm & + & + & 36.4 & Incon $^{\mathrm{m}}$ & - \\
\hline 29 Photinia sp. & hibernalis & - &,- 43.1 & - & - & - &,- 40.1 & - & - & \pm & + & + & 34.5 & Incon $^{\mathrm{m}}$ & - \\
\hline 30 Pieris japonica & hibernalis & - & - & - & - & - & - & - & - & - & + & + & - & $\mathrm{Neg}^{\mathrm{o}}$ & - \\
\hline 31 Pieris japonica & hibernalis & - & - & - & - & - & - & - & - & - & + & + & - & $\mathrm{Neg}^{\mathrm{o}}$ & - \\
\hline 32 Pieris japonica & hibernalis ${ }^{\mathrm{q}}$ & - & - & - & - & - & - & - & - & - & - & + & - & Neg & - \\
\hline 33 Rhododendron sp. & hibernalis & - & - & - & - & - & - & - & - & \pm & + & + & - & $\mathrm{Neg}^{\mathrm{o}}$ & - \\
\hline 34 Xylosma congestum & hibernalis & - & - & - & - & - & - & - & - & - & + & + & - & $\mathrm{Neg}$ & - \\
\hline 35 Camellia japonica & nemorosa & - & - & - & - & - & - & - & - & - & - & + & - & Neg & - \\
\hline 36 Camellia japonica & nemorosa & - & - & - & - & - & - & - & - & - & - & + & - & Neg & - \\
\hline 37 Pieris japonica & nemorosa & - & - & - & - & - & - & - & - & - & - & + & - & $\mathrm{Neg}$ & - \\
\hline 38 Umbellularia californica & nemorosa & - & - & - & - & - & - & - & - & - & - & + & - & $\mathrm{Neg}$ & - \\
\hline 39 Pieris japonica & nemorosa & - & - & - & - & - & - & - & - & - & - & + & 45.0 & $\mathrm{Neg}$ & \\
\hline 40 Arbutus unedo & $\mathrm{PgC}^{\mathrm{q}}$ & - & $\ldots^{r}$ & - & - & - & - & - & - & - & - & + & 40.2 & $\mathrm{Neg}$ & - \\
\hline 41 Arbutus sp. & $\mathrm{PgC}$ & - & - & - & - & - & - & - & - & - &,$+ \mathrm{w}$ & + & - & $\mathrm{Neg}^{\mathrm{o}}$ & - \\
\hline 42 Arbutus marina & $\mathrm{PgC}$ & - & - & - & - & - & - & - & - & - & - & + & - & Neg & - \\
\hline 43 Rhododendron sp. & $\mathrm{PgC}$ & - & - & - & - & - & - & - & - & - & - & + & - & Neg & - \\
\hline 44 Umbellularia californica & pseudosyringae & - & - & - & - & - & - & - & - & - & - & + & - & Neg & - \\
\hline 45 Umbellularia californica & pseudosyringae & - & - & - & - & - & - & - & - & - & - & + & - & $\mathrm{Neg}$ & - \\
\hline 46 Umbellularia californica & pseudosyringae & - & - & - & - & - & - & - & - & - & - & + & - & Neg & - \\
\hline 47 Umbellularia californica & pseudosyringae & - & - & - & - & - & - & - & - & - & - & + &,$- 42.8^{\mathrm{n}}$ & Neg & - \\
\hline 48 Umbellularia californica & pseudosyringae & - & - & - & - & - & - & - & - & - & - & + & - & Neg & - \\
\hline 49 Archtostaphylous manzanita & syringae & - &,- 46.0 & - & - & - & - & - & - & - & - & + & 37.6 & $\mathrm{Neg}$ & - \\
\hline 50 Arctostaphylos purissima & syringae & - & - & - & - & - & - & - & - & - & - & + & - & $\mathrm{Neg}$ & - \\
\hline 51 Arbutus unedo & syringae & - & - & - & - & 37.2 &,- 43.5 & - & - & - & - & + & - & $\mathrm{Neg}$ & - \\
\hline 52 Arbutus sp. & syringae & - & - & - & - & - & - & - & - & - & - & + & - & $\mathrm{Neg}$ & - \\
\hline 53 Arbutus sp. & syringae & - & - & - & - & - & - & - & - & - & - & + & - & $\mathrm{Neg}$ & - \\
\hline 54 Arbutus sp. & syringae & - & - & - & - & - & - & - & - & - & - & + & - & $\mathrm{Neg}$ & - \\
\hline 55 Rhododendron sp. & syringae & - & - & - & - & - &,- 41.4 & - & - & - & - & + & 40.7 & Neg & - \\
\hline 56 Rhododendron sp. & syringae & - & - & - & - & - & - & - & - & - & - & + & - & $\mathrm{Neg}$ & - \\
\hline 57 Rhododendron sp. & syringae & - & - & - & - & - & - & - & - & - & - & + & - & $\mathrm{Neg}$ & - \\
\hline 58 Rhododendron sp. & syringae & - & - & - & - & - & - & - & - & - & - & + & $40.1^{\mathrm{n}}$ & $\mathrm{Neg}$ & - \\
\hline 59 Rhododendron sp. & syringae & - & - & - & - & - & - & - & - & \pm & - & + &,- 41.0 & $\mathrm{Neg}$ & - \\
\hline 60 Rhododendron sp. & syringae & - & - & - & - & - & - & - & - & - & - & + & - & $\mathrm{Neg}$ & - \\
\hline
\end{tabular}


Differences in results were observed with the CSL ITS TaqMan real-time ITS marker (14) when it was run in the Hughes lab at the CSL compared with the approved USDA-APHIS procedure run at the USDA-APHIS-CPHST-NPGBL; this was likely due to the different forward primer that was used. The published CSL technique used by the Hughes lab (14) uses the forward primer Pram-114Fc while the technique used by the USDA-APHISCPHST lab (The USDA-APHIS-PPQ-approved CSL real-time technique) (33) uses Pram-114F. The difference between these primers is the base that is $3 \mathrm{bp}$ from the $3^{\prime}$ end of the primer; Pram-114F is an exact match for $P$. ramorum sequences whereas Pram-114Fc has a "G" rather than a "T". This base substitution was used to increase specificity of the marker system, reducing the potential for background amplification of P. lateralis (14); however, it increased the $\mathrm{C}_{\mathrm{t}}$ (reduced sensitivity) for $P$. ramorum detection while it reduced the potential for cross amplification. The USDA-APHIS-PPQ-approved procedure doesn't use this modified primer because a greater emphasis was placed on sensitivity of the assay.

The ITS region is commonly used as a target for diagnostic markers because there is a large amount of sequence data for many species available in GenBank and it is thought to be present in higher copy number than genes associated with housekeeping functions, thereby increasing the sensitivity of the molecular assay. Comparing the results from the three TaqMan real-time PCR assays of Bilodeau et al. (2) provides an opportunity to evaluate what this means from a standpoint of $C_{t}$ values obtained. When DNA from the field samples infected with $P$. ramorum was amplified in these three assays, the $C_{t}$ values for the ITS and elicitin markers were essentially the same, with both averaging 3.7 cycles less than the $\beta$-tubulin marker. Similar results were observed for the $C_{t}$ from purified DNA reported in the initial publication on these marker systems (2). Attempts to clarify the copy number of elicitin and $\beta$-tubulin genes in the $P$. ramorum genome were inconclusive (G. J. Bilodeau, unpublished) but, given the anticipated copy number of the rDNA repeats relative to housekeeping genes, it is likely that greater amplification efficiency for the elicitin and $\beta$-tubulin markers contributed to the similar level of sensitivity. Nonetheless, in this case, the use of these housekeeping genes as a diagnostic marker had either no or limited effect on assay sensitivity compared with the ITS marker.

The above-mentioned molecular detection methods are effective for determining if $P$. ramorum is present in field samples; unfortunately, this provides just some of the information of interest to a diagnostician (albeit perhaps the most important information from a regulatory standpoint). A more desirable technique would be one that could determine whether a Phytophthora sp. was present and clarify which species, thereby providing additional information about what species may be present in the sample sites under study. The SSCP procedure worked fairly well in this regard, although the need for an automated sequencer to run the samples may impact its adoption. Using DNA from pure cultures, the technique was able to differentiate a number of the Phytophthora spp. that were examined. Of the 107 MTs observed, 46 could be unambiguously identified based solely on the largest 6-FAM and HEX peak data. Although 61 of the 107 MTs were found to consist of groups that were indistinguishable based on this criterion alone, other criteria such as the presence of additional 6-FAM or HEX peaks not included in this analysis may increase the resolution of the SSCP procedure. The utility of the technique for field diagnostics was demonstrated by the correct identification of individual Phytophthora spp. or groups of potential Phytophthora spp. that were present in the field samples. At least for the hosts that were examined in this study, there did not appear to be any background amplification of plant DNA that would complicate data analysis, although this would need to be tested for a wider array of plant species before firm conclusions about specificity could be stated. Likewise, additional validation of the primers against Pythium spp. would be needed before the technique could be used for analysis of belowground plant parts. A major advantage of the procedure used in this submission compared with the initial reports in the literature $(18,19)$ was the use of a fluorescence-based automated DNA sequencer for data collection, which provides for more accurate determination of migration rates and for standardization across laboratories. It also has the added benefit that, if a five-dye-capable platform is utilized, one color can be used for the internal migration rate standard, two colors for an internal $P$. ramorum control, and the final two colors for an unknown sample.

Given the importance of correct diagnosis of $P$. ramorum, the ability to compare different molecular diagnostic techniques using the same target DNA should facilitate efforts to optimize pathogen detection. Although most of the molecular diagnostic methods tested functioned fairly well on an individual basis, the results clearly show the advantage of using the results from several different molecular detection methods; this was especially true when each method examined a different target region of the genome. From a regulatory perspective, it is important that the techniques utilized in diagnostics accurately detect $P$. ramorum but, from a research standpoint, it would also be useful to be able to identify other Phytophthora spp. that were present in the infected tissue. These data would be useful for clarification of host range and geographic distribution of particular species, as well as potentially identifying introduced or new species.

\section{ACKNOWLEDGMENTS}

Portions of this project were supported by a grant from USDA-APHISCHPST for F. Martin and M. D. Coffey, which is gratefully acknowledged. The WPC was funded in part by the UC/GRCP Annual Grants Program in Support of Imperiled Living Collections of Genetic Resources. We thank the following individuals for their contributions to this project; M. Carras at the USDA-ARS, Ft. Detrick, MD, for conducting the real-time PCR assays of the cox spacer region; D. Deemer, USDA Forest Service, Saucier, MS, for his skilled technical assistance with PCR and SSCP analysis; K. Maeda and L Bakerm at University of California (UC) Berkeley; J. Davis, S. Chow, S. Verdin, and E. Haw at UC Riverside for assistance with the Phytophthora cultures and DNA extraction and quantification; J. Tomlinson at the CSL, York, UK and E. Lovig, T. Irving, and M. Negrete at the CDFA. Mention of trade names or commercial products in this manuscript is solely for the purpose of providing specific information and does not imply recommendation or endorsement by the USDA.

\section{LITERATURE CITED}

1. Ayers, W. A., and Lumsden, R. D. 1975. Factors affecting production and germination of oospores of three Pythium species. Phytopathology 65:1094-1100.

2. Bilodeau, G. J, Lévesque, C. A., de Cock, A. W. A. M., Duchaine, C., Brière, S., Uribe, P., Martin, F. N., and Hamelin, R. C. 2007. Molecular detection of Phytophthora ramorum by RT-PCR using TaqMan, SYBR green and molecular beacons. Phytopathology 97:632-642.

3. Brasier, C. M. 2003. Sudden oak death: Phytophthora ramorum exhibits transatlantic differences. Mycol. Res. 107:258-259.

4. Bulluck, R., Shiel, P., Berger, P., Kaplan, D., Parra, G., Li, W. B., Levy, L., Keller, J., Reddy, M., Sharma, N., Dennis, M., Stack, J., Pierzynski, J., O' Mara, J., Webb, C., Finley, L., Lamour, K., McKemy, J., and Palm, M. 2006. A comparative analysis of detection techniques used in US regulatory programs to determine presence of Phytophthora ramorum in Camellia japonica 'Nucio's Gem' in an infested nursery in Southern California. Plant Health Progress. DOI:10.1094/PHP-2006-1016-01-RS.

5. California Department of Food and Agriculture. 2003. Oak Mortality Disease Control. Plant Quarantine Manual 455.1-455.6.

6. Canadian Food Inspection Agency. 2003. Phytosanitary requirements to prevent entry of Phytophthora ramorum associated with sudden oak death into Canada. Directive D-01-01.

7. Caten, C. E., and Jinks, J. L. 1968. Spontaneous variability of single isolates of Phytophthora infestans. I. Cultural variation. Can. J. Bot. 46:326-348

8. Cooke, D. E. L., Drenth, A., Duncan, J. M., Wagels, G., and Brasier, C. 
M. 2000. A molecular phylogeny of Phytophthora and related oomycetes. Fungal Genet. Biol. 30:17-32.

9. Drenth, A., Wagels, G., Smith, B., Sendall, B., O’Dwyer, C. O., Irvine, G., and Irwin, J.-A. G. 2006. Development of a DNA based method for detection and identification of Phytophthora species. Aust. Plant Pathol. 35:147-159.

10. Garbelotto, M., Rizzo, D. M., Hayden, M., Meija-Chang, M., Davidson, J. M., and Tjosvold, S. 2002. Phytophthora ramorum and sudden oak death in California: III. Preliminary studies in pathogen genetics. Pages 765-774 in: U. S. Dep. Agric. For. Serv. Gen. Tech. PSW-GTR-184, 5th Symp. Calif. Oak Woodlands. R. Standiford and D. McCreary, eds.

11. Hansen, E. M., Reeser, P. W., Sutton, W., Winton, L. M., and Osterbauer, N. 2003. First report of A1 mating type of Phytophthora ramorum in North America. Plant Dis. 87:1267.

12. Hayden, K., Ivors, K., Wilkinson, C., and Garbelotto, M. 2006. TaqMan chemistry for Phytophthora ramorum detection and quantification, with a comparison of diagnostic methods. Phytopathology 96:846-854.

13. Hayden, K. J., Rizzo, D., Tse, J., and Garbelotto, M. 2004. Detection and quantification of Phytophthora ramorum from California forests using a real-time polymerase chain reaction assay. Phytopathology 94:1075-1083.

14. Hughes, K.-J. D., Tomlinson, J. A., Griffin, R. L., Boonham, N., Inman, A. J., and Lane, C. R. 2006. Development of a one-step real-time polymerase chain reaction assay for diagnosis of Phytophthora ramorum. Phytopathology 96:975-981.

15. Ivors, K., Garbelotto, M., Vries, I.-D. E., Ruyter-Spira, C., Hekkert, B. T., Rosenzweig, N., and Bonants, P. 2006. Microsatellite markers identify three lineages of Phytophthora ramorum in US nurseries, yet single lineages in US forest and European nursery populations. Mol. Ecol. 15:1439-1505.

16. Ivors, K. L., Hayden K. J., Bonants P.-J. M., Rizzo D. M., and Garbelotto, M. 2004. AFLP and phylogenetic analyses of North American and European populations of Phytophthora ramorum. Mycol. Res. 108:378392.

17. Kannwischer, M. E., and Mitchell, D. J. 1978. The influence of a fungicide on the epidemiology of black shank of tobacco. Phytopathology 68:1760-1765

18. Kong, P., Hong, C., Richardson, P. A., and Gallegly, M. E. 2003. Singlestrand-conformation polymorphism of ribosomal DNA for rapid species differentiation in the genus Phytophthora. Fungal Genet. Biol. 39:238249.

19. Kong, P., Hong, C. X., Tooley, P. W., Ivors, K., Garbelotto, M., and Richardson, P. A. 2004. Rapid identification of Phytophthora ramorum using PCR-SSCP analysis of ribosomal DNA ITS-1. Lett. Appl. Microbiol. 38:433-439.

20. Kox, L.-F. F., van Brouwershaven, I. R., van de Vossenberg, B. T. L. H., van den Beld, H. E., Bonnets, P., and de Gruyter, J. 2007. Diagnostic values and utility of immunological, morphological, and molecular methods for in planta detection of Phytophthora ramorum. Phytopathology 97:1119-1129.

21. Kroon, L.-P. N. M., Verstappen, E.-C. P., Kox, L.-F. F., Flier, W. G., and Bonants, P.-J. M. 2004. A rapid diagnostic test to distinguish between American and European populations of Phytophthora ramorum. Phytopathology 94:613-620.

22. Martin, F. N. Mitochondrial haplotype determination in the oomycete plant pathogen Phytophthora ramorum. Curr. Genet. In press.

23. Martin, F. N., and Tooley P. W. 2003. Phylogenetic relationships among Phytophthora species inferred from sequence analysis of the mitochondrially-encoded cytochrome oxidase I and II genes. Mycologia 95:269-284.

24. Martin, F. N., and Tooley, P. W. 2004. Identification of Phytophthora isolates to species level using RFLP analysis of a PCR amplified region of mitochondrial DNA. Phytopathology 94:983-991.

25. Martin, F. N., Tooley, P. W., and Blomquist, C. 2004. Molecular detection of Phytophthora ramorum, the causal agent of sudden oak death in California, and two additional species commonly recovered from diseased plant material. Phytopathology 94:621-631.

26. Phytophthora ramorum. Code of Federal Regulations. 2003 ed. Title 7. Pt. 301, Subpart 92. Pages 142-148. U.S. Gov. Printing Office, Washington, DC

27. Rizzo, D. M., Garbelotto, M., Davidson, J. M., Slaughter, G. W., and Koike, S. T. 2002. Phytophthora ramorum as the cause of extensive mortality of Quercus spp. and Lithocarpus densiflorus in California. Plant Dis. 86:205-214.

28. Schena, L., Hughes, K.-J. D., and Cooke, D.-E. L. 2006. Detection and quantification of Phytophthora ramorum, $P$. kernoviae, $P$. citricola and $P$. quercina in symptomatic leaves by multiplex real-time PCR. Mol. Plant Pathol. 7:365-379.

29. Tomlinson, J., Barker, I., and Boonham, N. 2007. Faster, simpler, more specific methods for improved molecular detection of Phytophthora ramorum in the field. Appl. Environ. Microbiol. 73:4040-4047.

30. Tomlinson, J. A., Boonham, N., Hughes, K.-J. D., Griffin, R. L., and Barker, I. 2005. On-site DNA extraction and real-time PCR for detection of Phytophthora ramorum in the field. Appl. Environ. Microbiol. 71:6702-6710.

31. Tooley, P. W., Martin, F. N., Carras, M. M., and Frederick, R. D. 2006. Real-time fluorescent polymerase chain reaction detection of Phytophthora ramorum and Phytophthora pseudosyringae using mitochondrial gene regions. Phytopathology 96:336-345.

32. USDA Animal Plant Health Inspection Service. 2004. Sudden oak death: Phytophthora ramorum. Pest Detection and Management Programs. Published online by USDA Animal Plant Health Inspection Service.

33. USDA, APHIS PPQ CPHST. 2005. Quantitative multiplex real-time PCR (qPCR) for detection of Phytophthora ramorum using a TaqMan system on the Cepheid SmartCycler and the ABI 7900/7000. Document Control Number WI-B-T-1-6.10-26-2005.

34. USDA, APHIS PPQ CPHST. 2007. Conventional PCR assays for detection of Phytophthora ramorum. Document Control Number WI-B-T0-11.6-4-2007.

35. Werres, S., and Merlier, D. D. 2003. First detection of Phytophthora ramorum mating type A2 in Europe. Plant Dis. 87:1266.

36. White, T. J., Bruns, T., Lee, S., and Taylor, J. 1990. Amplification and direct sequencing of fungal ribosomal RNA genes for phylogenetics. Pages 315-322 in: PCR Protocols. A Guide to Methods and Applications. M. A. Innis, D. H. Gelfand, J. J. Sninsky, and T. J. White, eds. Academic Press, Inc., San Diego, CA.

37. Winton, L. M., and Hansen, E. M. 2001. Molecular diagnosis of Phytophthora lateralis in trees, water, and foliage baits using multiplex polymerase chain reaction. For. Pathol. 31:275-283. 